\title{
Sources of growth: measuring the knowledge based economy
}

Citation for published version (APA):

Meijers, H. H. M., \& Hollanders, H. J. G. M. (2003). Sources of growth: measuring the knowledge based economy. UNU-MERIT, Maastricht Economic and Social Research and Training Centre on Innovation and Technology. MERIT-Infonomics Research Memorandum Series No. 029

https://doi.org/10.26481/umamer.2003029

Document status and date:

Published: 01/01/2003

DOI:

10.26481/umamer.2003029

Document Version:

Publisher's PDF, also known as Version of record

\section{Please check the document version of this publication:}

- A submitted manuscript is the version of the article upon submission and before peer-review. There can be important differences between the submitted version and the official published version of record.

People interested in the research are advised to contact the author for the final version of the publication, or visit the DOI to the publisher's website.

- The final author version and the galley proof are versions of the publication after peer review.

- The final published version features the final layout of the paper including the volume, issue and page numbers.

Link to publication

\footnotetext{
General rights rights.

- You may freely distribute the URL identifying the publication in the public portal. please follow below link for the End User Agreement:

www.umlib.nl/taverne-license

Take down policy

If you believe that this document breaches copyright please contact us at:

repository@maastrichtuniversity.nl

providing details and we will investigate your claim.
}

Copyright and moral rights for the publications made accessible in the public portal are retained by the authors and/or other copyright owners and it is a condition of accessing publications that users recognise and abide by the legal requirements associated with these

- Users may download and print one copy of any publication from the public portal for the purpose of private study or research.

- You may not further distribute the material or use it for any profit-making activity or commercial gain

If the publication is distributed under the terms of Article $25 \mathrm{fa}$ of the Dutch Copyright Act, indicated by the "Taverne" license above, 


\section{MERIT-Infonomics Research Memorandum series}

Sources of growth: Measuring the knowledge based economy

Huub Meijers \& Hugo Hollanders

2003-029

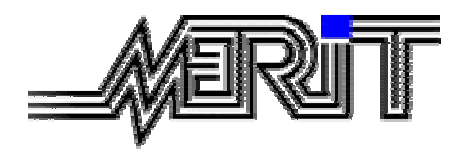

MERIT - Maastricht Economic Research Institute on Innovation and Technology

PO Box 616

6200 MD Maastricht

The Netherlands

T: +31433883875

F: +31433884905

http://meritbbs.unimaas.nl

e-mail:secr-merit@merit.unimaas.nl

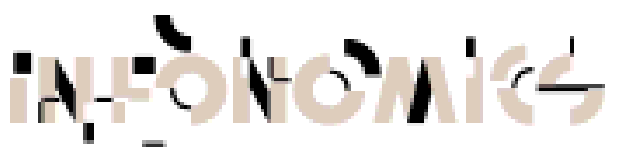

International Institute of Infonomics

c/o Maastricht University

PO Box 616

6200 MD Maastricht

The Netherlands

$\mathrm{T}:+31433883875$

$F:+31453884905$

http://www.infonomics.nl e-mail: secr@infonomics.nl 


\title{
Sources of Growth: Measuring the Knowledge Based Economy
}

\author{
Huub Meijers \\ Maastricht Economic Research Institute on Innovation and Technology \\ Maastricht University \\ P.O. Box 616 \\ 6200 MD Maastricht \\ huub.meijers at merit.unimaas.nl \\ http://www.merit.unimaas.nl/ \\ Hugo Hollanders \\ Maastricht Economic Research Institute on Innovation and Technology \\ Maastricht University \\ P.O. Box 616 \\ 6200 MD Maastricht \\ h.hollanders@merit.unimaas.nl \\ http://www.merit.unimaas.nl/
}

\begin{abstract}
For seven European countries macro-level indicators of the accumulation of intangible capital are developed. Using hedonic prices deflate investments in IT hardware, IT software and telecommunication equipment, for both intangibles and 'smart' tangibles capital stocks are constructed. These capital stock data are then used as an input to analyse the productivity effects for the business sector in the 1990s of all components, including traditional inputs like labour and (raw) capital. Increases in labour productivity can be explained by both an increase in labour quality and a further increase in capital deepening, esp. in the deepening of ICT capital. Several sensitivity analyses are carried out to test the robustness of the results for changes in the parameter assumptions in constructing the investment series and capital stocks.
\end{abstract}

Keywords: productivity growth, hedonic prices, ICT.

JEL codes: E31, O47 


\section{Introduction}

Investments in intangibles, which consist of investments in $\mathrm{R} \& \mathrm{D}$, education and training, software, royalties and licenses, and marketing, have grown faster than tangible investments in most developed countries in the last decades. The specific role of knowledge as an input factor in the production process has been (re-) emphasized by many authors and has led to the notions of knowledge based economies (see e.g. Abramovitz and David (1996), Nonaka and Takeuchi (1995), and Soete and ter Weel (1999)). This also has led to an increased notion of the importance of intangible investments vis-à-vis tangible investments. The measurement of tangibles is, due to a long tradition in economics, business and accounting, fairly standardized and is included in both business statistics as well as in the official statistics. However, the measurement of intangibles is still in its infancy, though its importance has been stressed by many authors (e.g. Griliches (1998), Brynjolfsson and Hitt (2000), Brynjolfsson, Hitt and Yang (2000), Schreyer (2000), and OECD (2001)).

Main goal of this chapter on indicators for the knowledge-based economy is to review and to develop a methodology to create stocks of knowledge based capital. Next to that, an actual construction of these stocks for some European countries is desired in order to analyse the results, which is the third goal. Rather then to make a distinction between tangibles and intangibles, the concept could be broadened to the knowledge base and should also include some tangible investments, like Information and Communication Technology (ICT) hardware and $R \& D$ equipment, next to intangible investments like $R \& D$ and software. So although investments in hardware do not belong to intangible investments as such, the nature of ICT hardware, being a general purpose technology in many cases that leads to network effects and to externalities, makes this type of investment more comparable to intangible investments rather than being included together with (raw) non-ICT investments. Moreover, the spread of knowledge is being facilitated by ICT hardware infrastructures like the Internet, which is another, but not less important, argument to treat ICT hardware together with intangibles. ${ }^{1}$ So the externalities of knowledge creation become more apparent if this knowledge spreads faster, more widely or both. The nature of analysis at hand is however closely related to the discussion on the productivity effects of ICT investments.

In order to create stocks of various forms of intangible capital, figures on investments, price developments and depreciation rates are needed and a methodology has to be used or to be developed. Concerning the latter, we closely follow the work done by the OECD (OECD (2000 and 2001)) were we treat the intangible fractions of the knowledge base in the same way as can be done for the tangibles. Except for factor specific characteristics, like the rate of depreciation and the development of (quality adjusted) prices, the methodology as such can be applied to intangibles as well. For this purpose, we will use the growth accounting framework as our starting point. This is described in Section 2. Price developments and accounting for quality changes are highly important in order to correctly measure the influence of various input factors. ${ }^{2}$ Methodologies to correct for such changes are reviewed in Section 3.

\footnotetext{
${ }^{1}$ From the endogenous growth theories the only reason why ICT investments in general, and in Internet technologies in particular, can lead to permanent increases of economic growth is the rapid spread of knowledge such that the innovation process is more efficient/productive.

${ }^{2}$ For a recent overview of biases in price indices and the Consumer Price Index in particular, see Hausman (2003).
} 
The actual description of the data employed and the construction of various capital stocks for R\&D, IT-Hardware, IT-Software, Telecommunications and the remaining "raw" capital stock are presented in Section 4. This is done for several European countries (Denmark, Finland, France, Germany, Italy, the Netherlands and the UK) as well as for the US. A main item discussed there is the use of quality-adjusted prices as to capture the real influence of these factors on the economy. But changing the prices of various input factors also leads to changes in the real value of output. These issues are discussed in Section 4 too. Finally, total factor productivity growth (TFP) is measured as a residual in this setting.

The growth accounting framework allows one to disentangle output growth as well as productivity growth into various components. This reveals the contribution of each factor to output and productivity growth under the condition that all factors are paid their marginal product. Section 5 describes these various contributions and special attention is paid to reveal the influence of quality-adjusted versus non quality-adjusted prices. Finally, Section 6 resembles the main conclusions.

\section{Growth accounting framework}

In order to measure the effects of investments in knowledge based capital goods, we take the growth accounting framework as a point of departure. Although not all relations between knowledge and growth are captured by this framework, for instance the contributions of specific sectors or investment goods to downstream and upstream sectors remain invisible ${ }^{3}$, it provides a well defined structure to analyse the relation between growth of various input factors, including knowledge related factors, to labour productivity and output growth at a macro-economic level. The standard growth accounting framework defines total factor productivity (TFP) growth as a Solow residual from a standard production function:

$$
Y=g(K, H)=A \cdot f(K, H)
$$

where $K$ is the capital input and $H$ is the labour input in terms of actual hours worked. $A$ denotes the Hicks neutral augmentation of aggregate inputs and this term corresponds to the level of technology. Since we exclude intermediate inputs in this analysis, output is based on value added. Here we take the total number of hours actually worked as a proxy of labour input since this reveals the true input of labour. Many authors, e.g. Jorgenson and Stiroh (2000) use the difference of hours worked relative to total employment as a proxy of labour quality in the production function. However, it is not clear at all how different changes of hours worked relative to total employment have their effects on the quality of labour. At one hand the number of hours worked per employee can be reduced gradually, which could improve the productivity per hour worked. Such marginal changes in working time are studied by e.g. Anxo and Bigsten (1989) and Leslie (1984). The results are mixed but show a slight improvement of productivity per hour due to reduced working time. But in non marginal changes of working time in the case of dividing the same numbers of hours among a larger number of employees, it is highly questionable whether this improves the quality of labour input in the same way as in the first situation since such far-reaching division of work inhabits high communication costs to transfer work related information etcetera. Since there

\footnotetext{
${ }^{3}$ See ten Raa and Wolff (2000) for such an analysis.
} 
is no indication which of these two effects prevails, we leave aside the changes in the quality of labour and concentrate on labour productivity per hour actually worked. ${ }^{4}$

Since we employ various forms of capital input, equation (2.1) has to be written as:

$$
Y=g\left(K_{1}, K_{2}, \ldots, K_{J}, H\right)=A \cdot f\left(K_{1}, K_{2}, \ldots, K_{J}, H\right) \quad j=1, . ., J
$$

where $J$ denotes the number of different capital goods.

If all factors are paid their marginal product, and if the production function inhibits constant returns to scale, and if technological change is Hicks neutral, the input shares in the production function can be used as weights for the input factors and the growth rate of output (e.g. value-added) can be written as:

$$
\hat{Y}=\hat{A}+\sum_{j} \bar{v}_{k j} \cdot \hat{K}_{j}+\bar{v}_{h} \cdot \hat{H}
$$

where hats denote growth rates and where $\bar{v}_{i}$ denotes the two-year moving average of the cost share of factor $i$ in total production costs:

$$
\bar{v}_{i, t}=\frac{v_{i, t-1}+v_{i, t}}{2}
$$

and

$$
v_{h}=\frac{w \cdot H}{p \cdot Y} \quad \text { and } \quad v_{k j}=\frac{u c c_{j} \cdot K_{j}}{p \cdot Y}
$$

where $w$ stands for the labour costs (hourly wage rate), $p$ for the value added price level and ucc for the user costs of capital for that specific capital good.

Note that for the income shares we use the average values since they reflect the longer-term output elasticities of the input factors. However, whether such a relation is fixed over a longer period or fluctuates gradually over time influences the size of the measured total factor productivity growth. The OECD's Productivity Manual (OECD, 2001) prefers a two-year moving average of the income shares for total factor productivity measures but it is questionable whether short run fluctuations and disequilibria should be captured in TFP growth. An alternative could be to use long term average values of the income shares as weights in the analysis, leading to different contributions of the various inputs and to different values of TFP growth. However, in order to be able to compare our results we stick to the two-year moving average as employed by many others. Finally, note that equation (2.3) is independent of the choice of the specification of the production function, as long as it inhibits constant returns to scale and as long as technological change is Hicks neutral.

\footnotetext{
${ }^{4}$ Another possibility is to disentangle labour into several components, e.g. educational background, age, sex etc. and to compute a quality adjusted index for labour input. Although this concept is preferable from a theoretical point of view, it also requires detailed data on individual characteristics and earnings. See Fosgerau, Hovgaard Jensen et al. (2000) for an implementation for Denmark and Ho and Jorgenson (1999) for the US.
} 


\subsection{Measuring capital investments, stocks and services}

This section describes the methodology used to derive the aggregate capital stock from individual assets in a consistent way. In this, we follow OECD (2001) and a similar methodology is used by e.g. Jorgenson and Stiroh (2000). The starting point is the capital stock of individual assets at the lowest level of aggregation for which we use the perpetual inventory method:

$$
S_{i, t}=S_{i, t-1}\left(1-\delta_{i}\right)+I_{i, t}=\sum_{\tau=0}^{\infty}\left(1-\delta_{i}\right)^{\tau} \cdot I_{i, t-\tau}
$$

where $S_{i, t}$ denotes the capital stock of asset $i$ at time t, $I_{i, t}$ denotes the investments in asset $i$ and $\delta_{i}$ denotes the asset specific constant rate of depreciation. The price index for valuing the capital stock of each individual asset is simply the price index of investments, $p_{i, t}^{c}$. Since we are interested in capital services, rather than the capital stock, we assume that the flow of capital services is equal to the two year moving average of the capital stock. Capital services of asset $i$ are defined as:

$$
K_{i, t}=\frac{S_{i, t}+S_{i, t-1}}{2}
$$

An alternative view is to define capital services directly as the age depreciated aggregate of half-year delayed investments. Both alternatives lead to exactly the same numerical values. Here we follow the first approach and distinguish between the capital stock and capital services flowing from that stock.

The price of capital services is, following e.g. Jorgenson (1963), defined by the user-costs of capital of individual assets. In this approach firms are assumed to be indifferent between earning a nominal rate of return, $r_{t}$, on an alternative investment or buying the asset, earning a rental fee and selling the asset after one period. I.e., investors are indifferent between:

$$
\left(1+r_{t}\right) \cdot p_{i, t-1}^{c}=u_{i, t}+\left(1-\delta_{i}\right) \cdot p_{i, t}^{c}
$$

rearranging yields the familiar concept of the user costs of capital:

$$
\begin{aligned}
u_{i, t} & =\left(1+r_{t}\right) \cdot p_{i, t-1}^{c}-\left(1-\delta_{i}\right) \cdot p_{i, t}^{c}=\left(r_{t}-\left(\frac{p_{i, t}^{c}-p_{i, t-1}^{c}}{p_{i, t-1}^{c}}\right)\right) \cdot p_{i, t-1}^{c}+\delta_{i} \cdot p_{i, t}^{c} \\
& =\left(r_{t}-\hat{p}_{i, t}^{c}\right) \cdot p_{i, t-1}^{c}+\delta_{i} \cdot p_{i, t}^{c}
\end{aligned}
$$

where a hat denotes the growth rate. Note that the user-costs-of-capital concept is important when dealing with fast depreciating assets like computer hardware. Moreover, also rapid price declines (given a constant quality) are important in this approach. A negative growth rate of computer prices and a high rate of depreciation lead to high user-costs of capital, relative to other, non high-tech, assets. 
Given the capital services and the user costs of capital, we can now derive the aggregate measure of capital services. The appropriate aggregation procedure of capital services should be based on user costs of capital concept and should use a superlative index number (Diewert, 1980). The Törnqvist and Fisher indices are both superlative and both can be used in the analysis. Here we will employ the Törnqvist index:

$$
\frac{K_{t}}{K_{t-1}}=\prod_{i=1}^{n}\left(\frac{K_{i, t}}{K_{i, t-1}}\right)^{\bar{v}_{i}}
$$

where the weights are the two-year moving averages of the value shares of capital income:

$$
\bar{v}_{i, t}=\frac{1}{2} \cdot\left(v_{i, t}+v_{i, t-1}\right) \quad \text { where } \quad v_{i, t}=\frac{u_{i, t} \cdot K_{i, t}}{\sum_{i=1}^{n} u_{i, t} \cdot K_{i, t}}
$$

and where $n$ denotes the number of different assets. Note that the numerical difference between the Törnqvist and the Fisher index is relatively small, as reported by e.g. OECD (2001). The price index for capital services, i.e. the user costs of aggregate capital services, is now equal to:

$$
u_{t}=\frac{\sum_{i=1}^{n} u_{i, t} \cdot K_{i, t}}{K_{t}}
$$

In a similar way, we can derive the aggregate capital stock:

$$
\frac{S_{t}}{S_{t-1}}=\prod_{i=1}^{n}\left(\frac{S_{i, t}}{S_{i, t-1}}\right)^{\bar{w}_{i}}
$$

where the weights are now the value shares of the aggregate capital stock:

$$
\bar{w}_{i, t}=\frac{1}{2} \cdot\left(w_{i, t}+w_{i, t-1}\right) \quad \text { where } \quad w_{i, t}=\frac{p_{i, t}^{c} \cdot S_{i, t}}{\sum_{i=1}^{n} p_{i, t}^{c} \cdot S_{i, t}}
$$

and the price index of the aggregate capital stock is:

$$
p_{t}^{c}=\frac{\sum_{i=1}^{n} p_{i, t}^{c} \cdot S_{i, t}}{S_{t}}
$$

which is based on that fact that the value of the aggregate capital stock should be equal to the sum of the value of all components. Finally, the aggregate volume of investments is defined as: 


$$
\frac{I_{t}}{I_{t-1}}=\prod_{i=1}^{n}\left(\frac{I_{i, t}}{I_{i, t-1}}\right)^{\bar{z}_{i}}
$$

where the weights are based on value shares in aggregate investments:

$$
\bar{z}_{i, t}=\frac{1}{2} \cdot\left(z_{i, t}+z_{i, t-1}\right) \quad \text { where } \quad z_{i, t}=\frac{p_{i, t}^{c} \cdot I_{i, t}}{\sum_{i=1}^{n} p_{i, t}^{c} \cdot I_{i, t}}
$$

and the aggregate price index for investments is equal to:

$$
p_{t}^{i}=\frac{\sum_{i=1}^{n} p_{i, t}^{c} \cdot I_{i, t}}{I_{t}}
$$

This framework allows us to create consistent stocks and services flowing from these stocks based on individual time series of all inputs. Note that superlative indices are used which implies that the growth accounting analysis, either based on aggregates or on individual input factors (e.g. ICT as an aggregate of IT Hardware, IT Software and Telecommunications) lead to the same results. Equations (2.3) to (2.5) then can be employed to disentangle output and labour productivity growth into several components, among which capital deepening from the various knowledge and non-knowledge based factors. This is the subject of Chapter 4 but first Chapter 3 will describe the construction of the datasets using the methodology shown above.

\section{Quality-adjusted prices}

As shown by Jorgenson (2001), US economic growth rose with 1.7 percent in the second half of the 1990s. An important explanatory factor is the doubling of the contribution of IT to output growth from .57 to 1.18 percent. And although computers still play an important role, software's contribution to output growth now exceeds that of computers. Also TFP rose sharply. Half of the .5 percent increase is due to the contribution of IT, and esp. of computers. But also the contribution from software to TFP almost doubled. ${ }^{5}$

Innovation will increase economic progress not only by creating new products and services, but also improving the quality of existing products and services. By improving the quality of an existing product, although the product's nominal price will remain the same or might even increase, its real price will decline, and as such it will increase the level of real income or real GDP. As it is often difficult to measure these quality improvements correctly, price changes are often overstated and as such real GDP is often understated, i.e. there is an upward bias in the CPI. Both economists and statisticians have spent considerable efforts in trying to improve this measurement error. Of the various methods, the hedonic regression approach is probably the most well known. Revived by Griliches in 1961 (Griliches, 1961 and Adelman

\footnotetext{
${ }^{5}$ These results are confirmed by Oliner and Sichel (2000), where we see a doubling of the relative contribution of ICT and a tripling of that of software to the growth rate of real nonfarm business output and nonfarm business labour productivity in the US, between 1974-1990 and 1996-1999.
} 
and Griliches, 1961), this approach extends earlier work dating back to the 1940s. This approach has been applied to a wide range of different commodities, and it is already being used in official price measurements in e.g. Canada, France, the Netherlands and the US. Subsections 3 and 4 will present a short review of the literature on computer hardware and software.

In a broader setting, these measurement problems are becoming more important as our economies are becoming more knowledge intensive. The introduction of new and improved products and services has increased the need for reducing the mismeasurement of the CPI. E.g., due to the introduction and diffusion of ICT, new technologies, products and services, which are characterised by higher quality, are introduced at increasing speed on the market, extending the consumers' products choice.

The implications of not correctly measuring price indexes due to quality improvements are far-reaching. ${ }^{6}$ Jorgenson (2001, p. 19) states "price indexes to deflate software investment fail to hold quality constant. This leads to an overstatement of inflation and an understatement of growth." What is true for software is also true for all other products and services, which undergo quality improvements. Official inflation rates are thus likely to be too high. One result will be that in those sectors or industries where nominal wages are indexed to the development of the CPI, will show increases in real wages, which are too high, but in comparison to other sectors and to the real development of that sector. In the longer run, this could seriously undermine a sector's international competitiveness. Furthermore, in the software development sector, quality improvements don't show up as improvements in labour productivity, and workers, esp. software developers, in this sector will thus not receive an appropriate increase in their real wages. ${ }^{7}$

\subsection{Quality improvements}

People are continuously confronted with quality improvements. Some of the most evident examples are the improving quality of automobiles and esp. computers over the past few decennia. E.g., Bode and van Dalen (2001) report for the Netherlands that between 1990 and 1999 nominal car prices increased by 20 percent, but that quality-corrected car prices remained constant. For the US, the Bureau of Labor Statistics (BLS) has conducted a whole range of studies into quality-adjusted prices for a.o. clothes dryers, microwave ovens, college textbooks, refrigerators, VCRs, DVD players, camcorders and consumer audio products, with all studies indicating a downward revision in the Consumer Price Index (CPI) if prices are corrected for quality improvements. Evidence for computer hardware will be discussed in detail in the section on the hedonic regression approach. On average, quality-adjusted prices declined by between 20 and 30 percent per year in the 1990s.

Quality improvements are no doubt one of the biggest challenges for those involved in price index compilation. With the pace of innovations leading to quality improvements increasing, the possible bias in the CPI also increases. Furthermore, different countries use different

\footnotetext{
${ }^{6}$ Shapiro and Wilcox (1996) state that CPI mismeasurement also matters for fiscal policies as, in the US, social security benefits, pension benefits, tax brackets and personal exemptions are indexed to the CPI. It also matters for monetary policies, as "the existence of upward bias in the rate of growth of the CPI suggests that true price stability will correspond to positive measured CPI inflation".

7 See also Volume 12 of the Journal of Economic Perspectives, which features six articles on CPI mismeasurement: Abraham et al. (1998), Boskin et al. (1998), Deaton (1998), Diewert (1998), Nordhaus (1998) and Pollak (1998).
} 
techniques to deal with quality improvements. As such, CPIs between countries become increasingly difficult to compare. Most statistical offices already, to some extent, adjust their CPI for quality improvements. The method most often used by most statistical offices is the matched-model method. Another approach is the hedonic regression method, which will be discussed in section 3 .

Several statistical offices use the matched-model method to control for quality changes in the CPI. In case of quality changes, the matched-model method compares the price of a product in the base period with the price of a comparable product (i.e. a new variety) in a later period. The observed price change between two product varieties can then be attributed 1) entirely to price change, 2) entirely to quality change, or 3) partially to price change and the remainder to quality change. Quality improvements to existing products lead to similar problems as the introduction of new products, the basket of products changes in such a way that the new or quality improved product increases the utility of the consumer. Unless this quality improvement is accounted for, this utility increase will not show up in the official statistics. Most statistical offices deal with this problem of new products in several ways. Implicit or indirect methods treat the change in quality as a residual, as that part of the observed price change that remains after calculating the 'pure' price change. Explicit or direct methods do so by making an explicit assumption or estimate about the change in quality (for more details see ILO (2001), chapter 13 on quality adjustments for CPIs). ${ }^{8}$

The matched-model method controls for quality changes in an indirect way. Theoretically, only if the market for quality is in equilibrium, the matched-model method will accurately measure quality-adjusted prices. Only then, after the introduction of a new product variety with a better price-quality ratio, will competitive pressures pull down the prices of existing products to equalize the quality-adjusted prices. The main critique against the matched-model technique is that the market for quality is not in equilibrium, that this technique can thus not fully capture quality changes and the technique of hedonic pricing is more appropriate.

\subsection{Hedonic pricing}

The technique of hedonic pricing dates back more than 70 years ago to the papers of Waugh (1928 and 1929). After a period of diminishing interest and research efforts, Griliches revived the interest in this technique in the 1960s starting with a study on quality-adjusted prices for automobiles (Griliches, 1961). Since then, this technique has been applied to a multitude of products, of which computers are the most prominent and probably also most studied products.

Hedonic pricing assumes that each product is made up of a multitude of definable characteristics, that for each characteristic a price can be estimated and that quality changes in a product can be viewed as adding a new characteristic to the product. The resulting price change can then be divided between the change resulting from adding the better quality characteristic and from a more general price increase (or decrease). As such, a qualityadjusted or 'pure' price can be calculated. Three questions should be addressed (Griliches, $1971^{9}$ ): 1) What are the relevant characteristics of a product?, 2) What is the relational form between prices and characteristics?, and 3) How should the "pure" price change from such data be estimated?

\footnotetext{
${ }^{8}$ ILO (2001): draft of chapter 13 on quality adjustments for CPIs.

${ }^{9}$ Zvi Griliches, "Introduction: Hedonic Price Indexes Revisited", in Zvi Griliches (1971, pp. 3-15).
} 
Determining which characteristics are important in determining a product's price is perhaps the most important question in hedonic pricing, But at the same time it is the most difficult one to answer, given the fact that these characteristics can only be determined in a highly subjective way. If one were to ask twenty people to identify the ten most important product features of a software program, the resulting lists will all be different. Some features will be mentioned more often than others, reflecting not only the importance of this feature but also to the simple fact that users will value different features differently and that not all users share the same level of information as to the possibilities of a certain product and it's features.

There are no general guidelines as to which characteristics should be included. Griliches (1971, p. 5) however, gives the strong advice that "... a characteristic and its price are important only to the extent that they capture some relevant fraction of the market". If a new product variety, with a new characteristic, is introduced on the market, but only captures a marginal size of that market, one should thus be careful including this new characteristic in the hedonic regression analysis. This however, requires detailed information about quantities sold, which is often not directly available. A more common procedure in determining which characteristics to include is to use so-called field economists or specialists, who are assumed to be able to identify, often from years of experience, which characteristics are important and which are not. Another procedure is to start off with a large list of characteristics, e.g. those listed in official CPI collection documents. Those variables for which the regression coefficients are not significant, will then be deleted form the set of characteristics, and the regression will be repeated, until all or most variables show up significantly.

Choosing the relational or functional form between prices and characteristics is another major problem. The semi-logarithmic form is the one which is empirically most convenient, and which is most often used. The natural log of the product's price is then regressed on a linear specification of the characteristics. Other, less frequently used forms, are the linear and the linear in logarithms form.

\subsection{Technical analysis ${ }^{10}$}

\subsubsection{Individual prices}

A consumer product is only by rare occasion a homogeneous product. Even for a 'simple' product as a coffee machine, the market offers tens if not hundreds of different varieties. Hedonic pricing assumes that the price of a product can be broken down into the prices of its characteristics or 'qualities'. We thus assume the following functional relation between the price of a product and it's quality characteristics:

$$
p_{i t}=f_{t}\left(x_{1 i t}, x_{2 i t}, \ldots, x_{k i t}, u_{i t}\right) \quad t \in[0, T]
$$

where $p_{i t}$ is the price of variety $i$ of a product at time $t, x_{j i t}$ the quality $j$ of variety $i$ at time $t$ where there are $k$ different product characteristics and $u_{i t}$ a disturbance term measuring all random factors. For explanatory reasons, we assume a semi-logarithmic functional form:

$$
\log p_{i t}=a_{0}+a_{1} x_{1 i t}+a_{2} x_{2 i t}+\ldots+a_{k} x_{k i t}+u_{i t}
$$

\footnotetext{
${ }^{10}$ This section draws heavily on Griliches (1961 and reprinted in Griliches, 1971, pp. 55-87).
} 
The $a_{j}$ coefficient can now be interpreted as an estimate of the percentage increase in price due to a one-unit change in quality $j$. Adding a time-dummy for each year except the base year, i.e. the dummy variable $D_{t}$ takes the value one in tear $t$ and zero otherwise,:

$$
\log p_{i t}=a_{0}+a_{1} x_{1 i t}+a_{2} x_{2 i t}+\ldots+a_{k} x_{k i t}+\sum_{t=1}^{T} a_{d t} D_{t}+u_{i t}
$$

allows the possibility to calculate quality changes between different years. The coefficient $a_{d t}$ provides us with an estimate of the average percentage increase in price between year $t$ and the previous year $t-1$, keeping the various qualities $j$ constant. Accumulating these qualityadjusted price changes, results in an estimate of the quality-adjusted price change between the base year and year $T$ for any individual product.

\subsubsection{Price indexes}

These quality-adjusted prices for individual products can be used directly to adjust the price index for quality changes of several underlying individual products. However, these price changes can also be estimated indirectly by creating an index of quality change. A hedonic regression of the equation in the previous paragraph results in estimates for the $a_{k}$ coefficients. Between period $t$ and $t-1$, the quality change can then be calculated as:

$$
g_{i, t-1}^{t}=\frac{p_{i, t}}{p_{i, t-1}}
$$

where $\hat{p}_{i t}=f_{t}\left(x_{1 i t}, x_{2 i t}, \ldots, x_{k i t}, u_{i t}\right)$ and $\hat{p}_{i, t-1}=f_{t-1}\left(x_{1 i, t-1}, x_{2 i, t-1}, \ldots, x_{k i, t-1}, u_{i, t-1}\right)$ are the predicted prices for each period based on the estimates for the $a_{k}$ coefficients. According to Griliches (1961, (1971, p.60)), "for a larger number of varieties, or models, these $g$ 's can be aggregated into a quality change index, using the same weights that are used in aggregating their prices in the price index". The observed price index between years $t$ and $t-1$ can then be adjusted for this quality change as follows:

$$
\text { true price index }=\frac{\text { observed price index }}{\text { quality change index }}=\frac{P_{t} / P_{t-1}}{\hat{P}_{t} / \hat{P}_{t-1}}=\frac{P_{t} / \hat{P}_{t}}{P_{t-1} / \hat{P}_{t-1}}
$$

where $P_{t}$ is the price index for year $t$ compiled out of the individual $p_{i t}$ 's.

\subsection{The use of hedonic pricing}

Various statistical offices are already using hedonic regression techniques in their CPI by calculating quality-adjusted prices for individual products. In the US, "the components deflated by hedonic techniques account for 18 percent of GDP" (Landefeld and Grimm, 2000 , p. 18). And this percentage might increase further in the near future, as the Bureau of Labor Studies (BLS) has recently published a whole range of reports on the use of hedonic 
regression techniques in various consumer products, of which some are already used in the construction of the CPI and others might be (very) soon. ${ }^{11}$

Table 3.1 Quality-adjusted prices in computer hardware

\begin{tabular}{|c|c|c|c|c|}
\hline Authors & Method & Type of hardware & Years covered & $\begin{array}{l}\text { Average annual } \\
\text { price decline }(\%)\end{array}$ \\
\hline \multirow{5}{*}{$\begin{array}{l}\text { Aizcorbe, Corrado and } \\
\text { Doms (2000) }\end{array}$} & MM & Desktop pc's & 1993-1998 & 28.9 \\
\hline & HR & Desktop pc's & 1993-1998 & 28.2 \\
\hline & MM & Mobile pc's & 1993-1998 & 23.1 \\
\hline & HR & Mobile pc's & 1993-1998 & 22.8 \\
\hline & MM & Servers/workstations & 1994-1998 & 20.7 \\
\hline \multirow{7}{*}{$\begin{array}{l}\text { Berndt, Dulberger and } \\
\text { Rappaport (2000) }\end{array}$} & Pooled & Personal computers & 1976-1999 & 25.9 \\
\hline & Pooled & Mobile pc's & 1983-1999 & 20.6 \\
\hline & Laspeyres & Mobile pc's & 1983-1999 & 27.8 \\
\hline & Paasche & Mobile pc's & 1983-1999 & 27.1 \\
\hline & Pooled & Desktop pc's & 1976-1999 & 27.5 \\
\hline & Laspeyres & Desktop pc's & 1976-1999 & 30.4 \\
\hline & Paasche & Desktop pc's & 1976-1999 & 24.3 \\
\hline Berndt and Griliches (1993) & HR & Microcomputers & 1982-1988 & 28 \\
\hline \multirow{4}{*}{$\begin{array}{c}\text { Berndt, Griliches and } \\
\text { Rappaport (1995) }\end{array}$} & MM & Personal computers & 1989-1992 & 20 \\
\hline & HR & Personal computers & 1989-1992 & 30 \\
\hline & & Mobile pc's & $1989-1992$ & 24 \\
\hline & & Desktop pc's & 1989-1992 & 32 \\
\hline Cartwright (1986) & HR & Mainframe computers & 1972-1984 & 13.8 \\
\hline Chow (1967) & HR & Mainframe computers & $1960-1965$ & 21 \\
\hline \multirow[t]{2}{*}{ Chwelos (1999) } & HR & Mobile pc's & 1990-1998 & 39.6 \\
\hline & & Desktop pc's & 1992-1998 & 32 \\
\hline Cohen (1988) & HR & Personal computers & 1976-1987 & $25-27$ \\
\hline \multirow[t]{2}{*}{ Cole et al. (1986) } & MM & Computer processors & 1972-1984 & 8.5 \\
\hline & HR & Computer processors & $1972-1984$ & 19.2 \\
\hline Dulberger (1989) & HR & Computer processors & $1972-1984$ & 18 \\
\hline Gordon (1989) & HR & $\begin{array}{l}\text { Mainframe and } \\
\text { mini computers }\end{array}$ & 1951-1984 & 22 \\
\hline Jorgenson (2001) & HR & All computers & 1959-1999 & 17 \\
\hline Kim (1989) & HR & Personal computers & 1976-1988 & $25-27$ \\
\hline $\begin{array}{l}\text { Nelson, Tanguay and } \\
\text { Patterson (1994) }\end{array}$ & HR & Personal computers & 1984-1991 & $17.5-24.6$ \\
\hline Triplett (1989) & HR & Mainframe computers & 1953-1972 & 27 \\
\hline
\end{tabular}

$\mathrm{MM}=$ matched-model method, $\mathrm{HR}=$ hedonic regression method

${ }^{11}$ These BLS studies cover the following products: clothes dryers (Liegey), camcorders (Shepler), college textbooks (Reese), consumer audio products (Kokoski et al.), DVD players (Liegey), microwave ovens (Liegey), refrigerators (Shepler) and VCRs (Thompson). 
Hedonic pricing techniques are used for a wide range of products, but they are mainly used in the area of computers and peripheral equipment. The number of studies on quality improvements in this area is substantial. Table 3.1 lists several of the most important studies, including some using the matched-model method. The studies on mainframe computers indicate annual price declines around 20 percent over the period from the 1950s to the mid 1980s, with prices declining faster in the beginning of this period. The market for personal computers is younger, with the introduction of the PC by IBM in 1981. Price decreases for the personal computer vary between 18 and 40 percent over the 1980s and 1990s. There doesn't seem to be any significant difference in price declines between desktop pc's and mobile pc's in the 1990s. Jorgenson (2001) reports a strong decline of real computer prices, compared to the real increase of the GDP deflator. Whereas the GDP deflator increased by almost 4 percent per year between 1959 and 1999, real quality-adjusted computer prices fell by 17 percent per year.

\subsection{Quality-adjusted software prices}

\subsubsection{Spreadsheet software}

It's hard to imagine every-day (working) life without the benefits of using spreadsheet software. In professional life, they are used for building and maintaining databases, for making all kinds of (repetitive) calculations, and even for running simple econometric regressions. As such, they must have contributed to the increase in labour productivity, although there is no direct evidence. One reason for this is that these programs undergo continuous quality improvements and are therefore not directly comparable with predecessors within a short period of time. The calculating power and amount of data a modern spreadsheet program like Microsoft Excel can handle is by no means comparable to the early programs developed by Lotus. ${ }^{12}$ Quality-adjusted price indexes are thus a first step in making these kinds of comparisons more reliable.

Table 3.2 Quality-adjusted prices in spreadsheet software

\begin{tabular}{lccc}
\hline Authors & Method & Years covered & $\begin{array}{c}\text { Average annual } \\
\text { Price decline }(\%)\end{array}$ \\
\hline Brynjolfsson and Kemerer (1996) & Hedonic & $1987-1992$ & 16 \\
Gandal (1994) & Hedonic & $1986-1991$ & 15 \\
McCahill (1997) & & & 9.0 \\
$\quad$ - "Gandal" & Hedonic & $1986-1993$ & 13.4 \\
- "Brynjolfsson and Kemerer" & Hedonic & $1986-1993$ & 9.6 \\
- "observation-inclusive" & Hedonic & $1986-1993$ & 4.5 \\
Oliner and Sichel (1994) & Matched-model & $1985-1993$ & \\
\hline
\end{tabular}

${ }^{\mathrm{a}}$ For 1986-1992 the average annual price declines are resp. 10.9, 16.9 and 11.9 percent.

Oliner and Sichel use a matched-model index to estimate quality-adjusted prices as these "provide the widest coverage across different software applications". Furthermore, they state that "hedonic indexes ... are difficult to implement for complex and hard-to-describe products like software" (Oliner and Sichel, 1994, p. 299). For 1985-1993 they collected price data from advertisements in several computing magazines. ${ }^{13}$ Table 3.2 shows that qualityadjusted spreadsheet prices fell by 4.5 percent per year between 1985 and 1993 and 4.0

\footnotetext{
${ }^{12}$ Lotus Corporation developed the first spreadsheet program Lotus 1-2-3 in 1982.

${ }^{13}$ E.g. PC Magazine, Personal Computing and PC World.
} 
percent between 1987 and 1993. Their results probably underestimate the price declines in the 1990s as they did not include "prices of upgrades, products purchased in software 'suites', or products bundled with hardware" (Oliner and Sichel, 1994, p. 300).

Gandal (1994) uses data on spreadsheet programs taken from DATAPRO Research Group, leading to a dataset of 91 observations for the period 1986-1991. Gandal starts with 13 dummy variables assigning a value of 0,1 or 2 depending if the specific program supports a certain feature, one variable describing the power of the program and 5 time dummies for each of the years 1987 to 1991. As a dependent variable he uses the natural log of the list price for a single copy of the program. Gandal splits his sample in two, introducing a sub sample for 1986-1988 and one for 1989-1991, and then runs the same regression for each of these sub samples. ${ }^{14}$ The quality-adjusted price indexes that can be calculated from these regression results, which are shown in Table 3.3, result in an average yearly decline of quality-adjusted prices of 15 percent.

Brynjolfsson and Kemerer (1996) use data from DataQuest, International Data Corporation (IDC) and trade press reviews to find list prices for 22 unique spreadsheet programs for the time period 1987-1992. In total their dataset includes 93 observations. Data about product characteristics were taken from National Software Testing Labs' (NSTL) Software Digest Ratings Reports. Brynjolfsson and Kemerer semi-logarithmic base model omits all variables not significant at the $90 \%$ confidence level. Quality-adjusted prices declined by 16 percent per year on average, a result similar to the one reported by Gandal. Replacing the time variable by individual time dummies for the years 1988-1992, results in similar coefficient estimates for the other variables. The quality-adjusted price indexes resulting from this regression are reported in Table 3.3. Except for the price increase between 1987 and 1988, these price indexes resemble those reported by Gandal.

Table 3.3 Price indexes for spreadsheet software (1987=1.00)

\begin{tabular}{lcccccccc}
\hline & 1986 & 1987 & 1988 & 1989 & 1990 & 1991 & 1992 & 1993 \\
\cline { 2 - 8 } & 1.08 & 1.00 & 0.69 & 0.54 & 0.52 & 0.49 & & \\
Gandal (1994) & & & & & & & & \\
& & 1.00 & 1.07 & 0.77 & 0.70 & 0.54 & 0.52 & \\
Brynjolfsson and Kemerer (1996) & & & & & & & & \\
McCahill (1997) & & & & & & & & \\
- "Gandal" & 1.11 & 1.00 & 0.96 & 0.71 & 0.57 & 0.73 & 0.56 & 0.57 \\
- "Brynjolfsson and Kemerer" & 1.21 & 1.00 & 0.92 & 0.46 & 0.51 & 0.54 & 0.40 & 0.44 \\
- "observation-inclusive" & 1.37 & 1.00 & 1.07 & 0.70 & 0.67 & 0.78 & 0.64 & 0.68 \\
\hline
\end{tabular}

McCahill (1997) reproduces the results from these earlier studies for the time period 19861993. His first regression includes only variables listed in Gandal. However, these are not all the same as those used in Gandal's 'preferred equation'. There is also a significant difference between the value of some of the estimated coefficients and the adjusted $\mathrm{R}^{2}{ }^{15}$ His second regression only includes variables as listed in Brynjolfsson and Kemerer and these regression results are more in line with the original ones. His third regression includes variables listed in both studies, but only takes into account variables if data is available for all observations, his so-called 'observation-inclusive' regression. The corresponding price indexes are shown in Table 3.3. There are large differences between the values reported for 1992 and 1993. The

\footnotetext{
${ }^{14}$ The regression results for his 'preferred equation' are shown in Table 4.4 in Hollanders and Meijers (2002).

${ }^{15}$ McCahill states that this could be due "to the use of different source data ... and to the necessary occasional judgmental interpretations of quality characteristics ..." (McCahill, 1997, p. 9).
} 
corresponding declines in quality-adjusted price indexes, as shown in Table 3.2, vary between 9.0 and 13.4 percent for the time period 1986-1993.

As these studies show, there are large differences in outcomes, depending on the time period studied, the product characteristics included in the hedonic regression, and different data sources used. Although all results point in the same direction, a decline in quality-adjusted prices over the late eighties and beginning nineties, the exact magnitude of this decline remains unclear, with average annual price declines ranging from 9 to 16 percent. The cause for all this seems quite clear: a lack of data for the product characteristics identified in these studies. Not only are data simply missing for some of these characteristics, but for those characteristics for which data are available, different sources have to be used to construct useable timeseries. These sources are mainly private sources that do not provide coherent and comparable data. Furthermore, although spreadsheet programs seem to be a rather clear defined product group, identifying which characteristics contribute to a product's price is not without dispute. Of the 14 variables identified by Gandal and 28 by Brynjolfsson and Kemerer, only 9 are found in both studies. This underlines exactly one of the main criticisms of hedonic pricing: the subjective nature in which descriptive variables are chosen.

\subsubsection{Word processing software}

Oliner and Sichel estimate quality-adjusted price indexes for word processing software using the matched-model method. For 1985-1993, they find that these prices decline by 2.6 percent per year, as shown in Table 3.4.

Table 3.4 Quality-adjusted prices for word processing software

\begin{tabular}{lccc}
\hline Authors & Method & Years covered & $\begin{array}{c}\text { Average annual } \\
\text { price decline (\%) }\end{array}$ \\
\hline $\begin{array}{l}\text { McCahill (1997) } \\
\text { - "observation-inclusive" }\end{array}$ & Hedonic & $1985-1994$ & 15.1 \\
- "variable-inclusive" & Hedonic & $1985-1994$ & 18.5 \\
Oliner and Sichel (1994) & Matched-model & $1985-1993$ & 2.6 \\
\hline
\end{tabular}

The number of hedonic studies on spreadsheet software was already small with only three, for word processing software it is even worse. Only McCahill provides results for this type of software using hedonic regression techniques. McCahill uses NSTL data for obtaining data on prices and for choosing 45 product characteristics out of 341 product features identified by NSTL, resulting in a dataset of 155 observations for the time period 1985-1994. McCahill gives results for two regressions, the 'observation-inclusive' one including 20 variables for which data are available for all observations and the "variable-inclusive" one, including an additional 25 variables for which some data is missing. As Table 3.4 shows, quality-adjusted prices decline with 15.1 resp. 18.5 percent per year. The price indexes calculated using these regression results are reported in Table 3.5.

Table 3.5 Price indexes for word processing software $(1987=1.00)$

\begin{tabular}{lllllllllll}
\hline & 1985 & 1986 & 1987 & 1988 & 1989 & 1990 & 1991 & 1992 & 1993 & 1994 \\
\cline { 2 - 10 } McCahill (1997) & & & & & & & & & & \\
- "observation-inclusive" & 1.31 & 1.12 & 1.00 & 0.93 & 0.69 & 0.65 & 0.38 & & 0.30 \\
- "variable-inclusive" & 1.65 & 1.23 & 1.00 & 0.70 & 0.61 & 0.17 & 0.16 & 0.26 \\
\hline
\end{tabular}




\subsubsection{BEA quality-adjusted price indexes}

For the US, the BEA (Bureau of Economic Analysis) provides quality-adjusted prices for prepackaged software, custom software and own-account software for 1959-1998 in a study by Parker and Grimm (2000). These price indexes are composed of hedonic, matched-model and other price indexes for several time periods.

For pre-packaged software, the quality-adjusted price indexes can be broken down into the following sub periods:

- 1959-1984: the price index is based on the BEA price index for computers and computer peripherals. The price index for pre-packaged software is calculated as 60 percent of the annual change in this index.

- 1985-1993: the price index is made up for 50 percent of a BEA hedonic price index for spreadsheets, databases and word processors, calculated using the procedure set out by Brynjolfsson and Kemerer (1996) and Gandal (1994), and for 50 percent of a matched-model index for spreadsheets and word processors conform Oliner and Sichel (1994). This choice for an unweighted price index for 1985-1993 reflects "the concern that the hedonic index may overstate price declines because over time, the characteristics of high-priced packages with limited sales are incorporated into lower priced packages that have much greater sales" (Parker and Grimm, 2000, p. 15).

- 1994-1997: BEA matched-model price index for 'business-oriented pre-packaged programs', calculated using the procedure set out by Oliner and Sichel (1994). This index is adjusted upward with an adjustment factor of 3.15 percent to reflect the fact that new versions of software are either not included in the matched-model price index or are included with some delay.

- 1998: Bureau of Labor Statistics (BLS) producer price index for applications software. The same upward adjustment factor of 3.15 percent is used.

For own-account and custom software, no direct price indexes are calculated. For ownaccount software, price indexes are input-cost indexes that are calculated indirectly as a weighted average of compensation rates for system analysts and computer programmers and the costs for intermediate inputs. It is assumed that there is no improvement in productivity over time for system analysts and computer programmers. ${ }^{16}$ These compensation rates are calculated separately for business and government as wages developed differently over time. For custom software, the price index is assumed to be a weighted average of 75 percent of price changes for business own-account software and 25 percent of price changes for prepackaged software.

Price estimates for software investment in current and real quality-adjusted prices are shown in Table 3.6. The price estimates show that for the US quality-adjusted prices for prepackaged software have fallen sharply, prices for custom software have been stable since the beginning 1980s, and prices for own account software have been increasing at a steady pace (both business and government). The sharp declines in pre-packaged software prices reflect

\footnotetext{
${ }^{16}$ As pointed out by Bruce Grimm in an email conversation, BEA has been experimenting by assuming a 2 percent-per-annum rate of increase for labour productivity for computer programmers and system analysts (roughly the long-term trend for all of the non-farm business sector). This did not make a significant difference in real software investment and, reflecting the way the estimates were constructed, no difference in currentdollar software investment. As the effect was only modest, and the assumption of 2 percent was arbitrary, BEA is not going to use these results in their official price estimates. For the near future no further experiments are to be expected.
} 
economies of scale. Own account software prices are driven by wage costs and costs of intermediate products. As there are no economies of scale and no learning effects which would put a downward pressure on prices, own account software prices have been increasing. Custom software prices remain stable as the downward pressure due declining prices of incorporated pre-packaged software cancel out the upward pressure due to increasing wage costs and intermediate costs (Parker and Grimm, 2000).

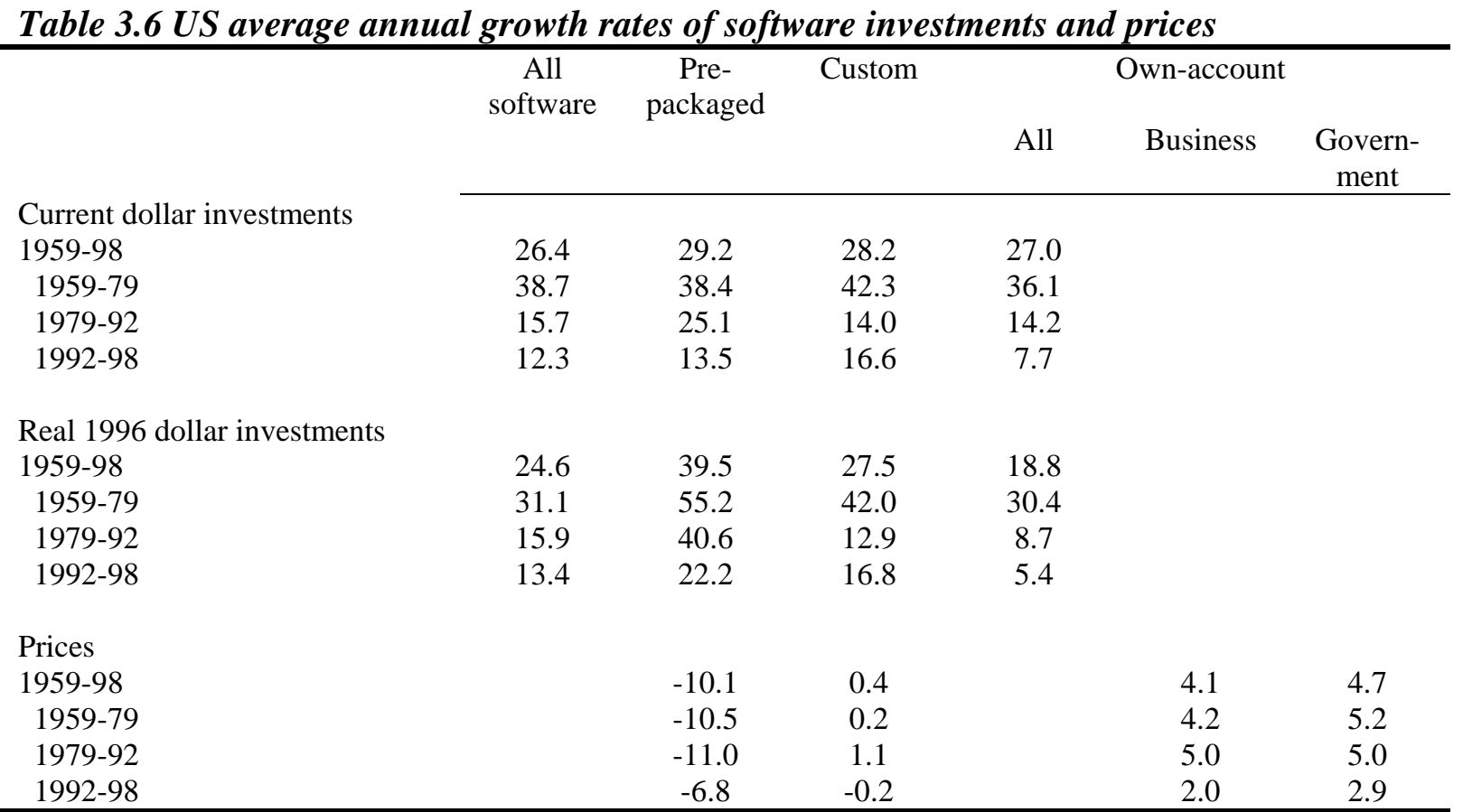

Source: Parker and Grimm (2000).

Conform the approach followed by Schreyer (2000), who uses US hedonic price indexes for IT equipment to update official German non-quality-adjusted price indexes for IT equipment for quality changes ${ }^{17}$, BEA's quality-adjusted software prices will be used to update the few time series for software investments available within Europe in Section 4.

\section{Data: construction of investment and capital stock series}

For seven European countries (Denmark, Finland, France, Germany, Italy, the Netherlands and the United Kingdom) and the United States we have constructed (and collected) data on intangible investments and intangible capital stocks For IT hardware, IT software and telecommunication equipment in particular, harmonised quality-adjusted prices have been calculated to construct investment series in constant prices. These intangible quality-adjusted investment data are then used to construct stocks of intangible capital. Together with the traditional inputs labour and (raw) capital, these intangible capital stocks are then used in Section 4 as an input to analyse the productivity effects and growth effects of ICT and R\&D. In this section we briefly describe the data sources used and the procedures followed to construct the investment data and capital stocks.

\footnotetext{
${ }^{17}$ Schreyer (2000) compares the hedonic price indexes for US IT equipment with the price indexes for US nonICT investment goods. The smoothed difference between these indexes is then assumed to be valid for all other countries. Applied to German non-quality adjusted IT prices, Schreyer calculates a 'harmonised series' which does take into account quality changes.
} 
Both public and private data sources have been used to collect the raw data for the business enterprise sector used in constructing series of intangible investments. The OECD serves as our main data source for all general economic data (GDP, domestic product of industry, gross fixed capital formation (GFCF), business capital stock, business employment, compensation of employees, GDP deflator, business investment deflator, exchange rate, purchasing power parities (PPP) and interest rates), data on business R\&D expenditures (BERD) and data on telecommunication investments. ICT expenditure data were taken from Eurostat, and for annual average hours actually worked we used private data from the Groningen Growth Development Centre (GGDC). ${ }^{18}$ US private fixed investment data and quality-adjusted price deflators for computers, software and communication equipment were taken from the US Bureau of Economic Analysis. ${ }^{19}$

\subsection{R\&D investment and capital stock series}

In the current SNA R\&D expenditures are not treated as investment but as intermediate consumption. Our enlarged concept of intangible investment should thus comprise all R\&D expenditures. According to Croes (2000) not all business R\&D expenditures should be classified as intangible investments but only current expenditures. These include labour costs and other current costs as expenditures for travelling, maintenance and insurance. Capital expenditures, comprising expenditures for land, buildings, machinery and instruments, should thus be excluded from intangible investments, as these are already included in GFCF. From a theoretical point of view Croes might be right, $R \& D$ equipment investments are tangible so they should be excluded from the intangible capital stock by definition, but from an analytical point of view treating all $R \& D$ expenditures as investments and thus including all intangible and tangible investments in the BERD capital stock seems best when analysing the productivity effects of $R \& D$.

For most countries data on BERD in current national currencies are available for 1967-1999. To calculate R\&D investment flows in both 1995 national currencies and 1995 purchasing power parity dollars (PPP\$), we first replaced missing values using linear interpolation. The time series were then extrapolated to $1960-2002$ by applying the $R \& D$ intensity of the last year known to the 1960-2002 GDP time series. The resulting series were converted in 1995 national currencies by dividing them by the GDP deflator and by dividing these by the 1995 PPP into 1995 PPP\$ investments. BERD capital stocks were constructed using the Perpetual Inventory Method (PIM) with a log-linear retirement pattern, assuming a depreciation rate of $15 \%$ and an initial 1960 capital stock of 0 . Table 4.1 shows some descriptive growth statistics for these capital stocks. On average, BERD capital stocks grew faster in the $2^{\text {nd }}$ half of the 1990s, mainly caused by the sharp increase in the Finnish growth rate. The weighted average shows a decline in the $2^{\text {nd }}$ half of the 1990s, caused by a slower growth of the BERD capital stocks in all major EU countries. The highest growth rates for total BERD for 19902000 were attained by Finland and Denmark. The high growth rates for Finland can first be explained by the sharp increase in BERD as a percentage of GDP with $1.01 \%$-point in the 1990s. The Finnish growth acceleration in the $2^{\text {nd }}$ half of the 1990 s is further spurred by a strong recovery of the economy. In 1990-1995 real GDP witnessed an annual negative

18 University of Groningen and The Conference Board, GGDC Total Economy Database, 2002, http://www.eco.rug.nl/ggdc

${ }^{19}$ Table 3.1 in Meijers and Hollanders (2002) gives a full overview of the data and data sources that were used as raw inputs into the construction of the investment and capital stock series.

${ }^{20} \mathrm{Cf}$. Griliches (1980). The assumed depreciation rate of $15 \%$ transforms into an average service live of 4 years. 
growth of $0.5 \%$, in 1995-2000 real annual growth had accelerated to $4.9 \%$. Table 4.1 also shows that the share of the R\&D capital stock in GDP grew fastest in Denmark and Finland. For the other countries growth has either been small or even negative.

\section{Table 4.1 Descriptive growth statistics BERD Capital stock}

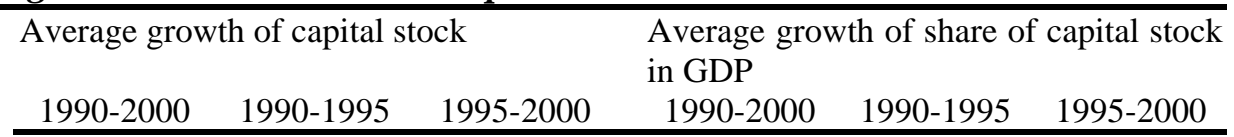

\begin{tabular}{|c|c|c|c|c|c|c|}
\hline $\mathrm{DEN}$ & 6.53 & 6.43 & 6.53 & 4.26 & 3.94 & 3.55 \\
\hline FIN & 8.45 & 6.05 & 10.50 & 6.34 & 6.09 & 5.42 \\
\hline FRA & 2.98 & 3.93 & 1.88 & 1.12 & 0.83 & 0.44 \\
\hline GER & 1.99 & 2.04 & 1.71 & -0.14 & 0.09 & 0.15 \\
\hline ITA & 1.31 & 2.00 & 0.28 & -0.30 & -0.79 & -1.06 \\
\hline NLD & 2.35 & 1.11 & 3.59 & -0.66 & -0.39 & -0.11 \\
\hline UK & 1.19 & 1.34 & 0.94 & -0.84 & -1.09 & -1.35 \\
\hline US & 3.41 & 2.57 & 4.09 & 0.17 & 0.23 & -0.05 \\
\hline EU: arithmetic average & 3.54 & 3.27 & 3.63 & & & \\
\hline EU: weighted average & 2.17 & 2.37 & 1.78 & & & \\
\hline
\end{tabular}

\subsection{ICT investment and capital stock series}

Total ICT expenditures are divided into expenditures on IT hardware, IT software and telecommunications equipment. The expenditure data for hardware and software were taken from Eurostat. ${ }^{21}$ Other possible sources are EITO ${ }^{22}$ and WITSA/IDC. ${ }^{23}$ Following Daveri (2000), we do not use Eurostat data on telecommunications equipment expenditures, but OECD data on total PTO investments (Public Telecommunications Operators) as a first proxy for investments in telecommunications equipment. For all countries, except for the US for 2000 and 2001, WITSA/IDC ICT expenditures are higher than Eurostat ICT expenditures. ${ }^{24}$ Although the difference is relatively small up until 1999 (on average 4\%), this difference has increased rapidly to $13 \%$ over the last two years. Comparing Eurostat and EITO data, we see for all countries that Eurostat data are on average $13 \%$ higher than EITO data. ${ }^{25}$ But this difference has been declining over time and is now less than 10\%, with EITO data even exceeding Eurostat data for Italy and the US from 1998 respectively 1995 onwards. Eurostat data are based on WITSA/IDC data for the period 1992-1999. This explains why the difference between these two data sources is quite small. The Eurostat 2000-2001 data were constructed by extrapolating the 1999 data by using EITO growth rates for these years. This explains the sharp increase in the difference between Eurostat and WITSA/IDC data in these two years. As one agreed-upon database is lacking, we have chosen to use Eurostat data for hardware and software expenditures as these data are based on and used by the OECD.

\footnotetext{
${ }^{21}$ Structural indicator, data based on OECD data. The OECD uses WITSA/IDC data as its primary source.

${ }^{22}$ As of 1993 the European Information Technology Observatory publishes a yearbook "which presents the most comprehensive and up-to-date data including the entire information and communications technology market in Europe". However, the ICT data in this yearbook differ (sometimes substantially) from Eurostat data.

${ }^{23}$ WITSA/IDC publish their Digital Planet on a bi-annual basis. Reports published in 1998, 2000 and 2002 cover ICT data for 55 countries. Also these data differ from Eurostat data.

${ }^{24}$ This difference is the result from the fact that the OECD subtracts private expenditure for packaged software and certain types of R\&D related expenditure from the WITSA/IDC data.

${ }^{25}$ But there is a sharp difference between IT and Telecommunications expenditures. IT expenditures as published by EITO are on average even $28 \%$ smaller than those reported by Eurostat. However, for Telecommunications expenditures we see that EITO data are on average 10\% higher than those reported by Eurostat.
} 
From the BEA we have used US data on private fixed investment and quality-adjusted prices for Computers and peripheral equipment, Software and Communication equipment. ${ }^{26}$ Table 4.2 summarizes data availability for the ICT variables.

\section{Table 4.2 ICT data availability}

\begin{tabular}{|c|c|c|c|}
\hline & & $\begin{array}{c}\text { DEN, FIN, FRA, GER, } \\
\text { ITA, NLD, UK }\end{array}$ & US \\
\hline \multicolumn{4}{|c|}{ Eurostat } \\
\hline & IT hardware expenditures (\% of GDP) & 1992-2001 & 1992-2001 \\
\hline & IT software expenditures ( $\%$ of GDP) & 1992-2001 & 1992-2001 \\
\hline \multicolumn{4}{|c|}{ OECD } \\
\hline & PTO investments (mln national currencies) & 1980-1999 & 1980-1999 \\
\hline \multicolumn{4}{|c|}{ Computer: } \\
\hline & ○ Investments (mln US dollars) & & $1980-2000$ \\
\hline & - Price deflator $(1996=1)$ & & $1960-2000$ \\
\hline \multicolumn{4}{|c|}{ Software: } \\
\hline & ○ Investments (mln US dollars) & & $1980-2000$ \\
\hline & ○ Price deflator $(1996=1)$ & & $1960-2000$ \\
\hline \multicolumn{4}{|c|}{ Telecommunications } \\
\hline & ○ Investments (mln US dollars) & & $1980-2000$ \\
\hline & ○ Price deflator $(1996=1)$ & & $1960-2000$ \\
\hline
\end{tabular}

\subsubsection{Adjustment ratios}

The first step in constructing ICT capital stocks is to convert the expenditures data into investments following Daveri (2000). For IT hardware Daveri compares US WITSA/IDC expenditures data on IT hardware with BEA data on private fixed investment for computers and peripheral equipment. WITSA/IDC data includes household, educational and government spending, which should not be included in business investment data. WITSA/IDC data should thus be adjusted downward. For this Daveri calculates the average ratio between the BEA investment series and the WITSA/IDC expenditures series. This adjustment ratio can then be used to adjust IT hardware spending downwards for the EU countries. Using Eurostat data, we calculated an adjustment ratio of 0.563 for 1992-2000.

For IT software Daveri compares WITSA/IDC data on IT software spending with BEA investment data on software. WITSA/IDC data do not include internal software spending, so BEA investment data are used to calculate an adjustment ratio to adjust the WITSA/IDC series upwards for the EU countries. Daveri's 1992-1997 ratio of 2.289 differs significantly from the 1992-2000 ratio of 0.697 we calculated using Eurostat data. This difference is caused by different definitions for software expenditures. WITSA/IDC distinguishes six ICT categories: IT Hardware, IT Software, IT Services, Internal spending, Other office equipment, and Telecommunications services. Eurostat distinguishes only four categories: IT Hardware, IT Software, Other IT services, and Telecommunication equipment and services. With (part of) internal spending included in software spending, Eurostat software spending is on average 3 times as high as WITSA/IDC software spending.

For Telecommunications equipment Daveri prefers to use OECD data on PTO investment as WITSA/IDC data includes spending on telecommunications services, which should not be accounted for as investments. Daveri calculates a 1980-1997 adjustment ratio of 1.786, which

${ }^{26}$ BEA NIPA Table7.8: Chain-Type Quantity and Price Indexes. 
is, due to the drop in this ratio in the $2^{\text {nd }}$ half of the 1990 s and our shorter time period, above our 1992-2000 ratio of 1.484 .

Table 4.3 ICT price indices: average annual percentage change

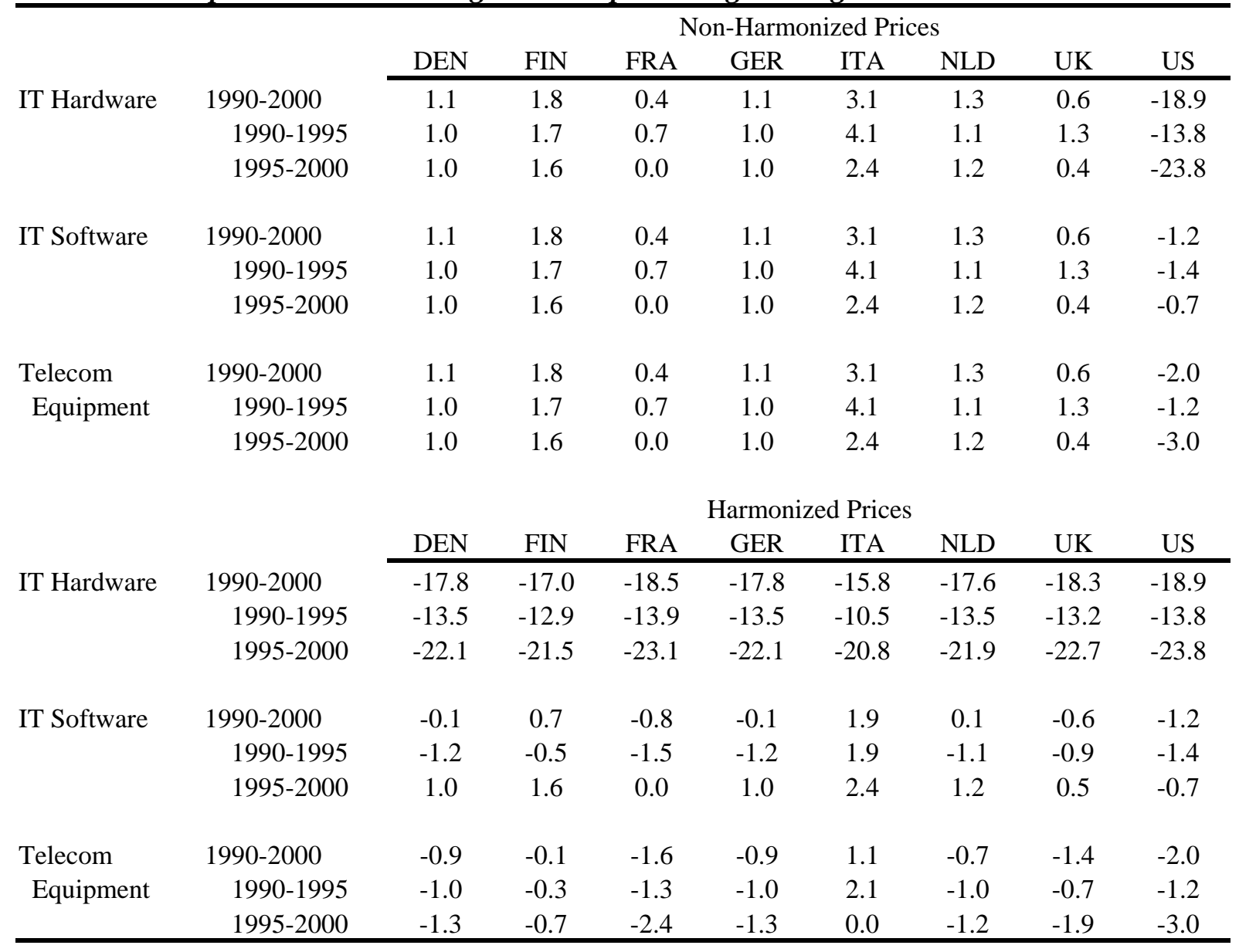

\subsubsection{ICT Capital stocks}

Investment series for IT hardware, IT software and telecom equipment in both 1995 national currencies as in 1995 PPP\$ were calculated by first extrapolating the available PTO series to 2000-2001 by applying the 1999 PTO/GDP ratio to the 2000-2001 GDP values and by then dividing these by the dollar exchange rate. IT hardware and IT software expenditures series were updated to include 1981-1991 by applying the average growth rate for ICT/GDP for 1992-2001 to the 1981-1991 GDP values. By using the adjustment rations and the dollar exchange rate these were then converted into US\$ investment series. The BEA qualityadjusted price deflators are updated to include 2001-2002 by applying each deflator's average growth rate for 1991-2000 to a 3-year weighted average for 1999 (based on 1998-2000 data). Following Schreyer (2000), two harmonized price indices are calculated. For the first, we adjusted the BEA quality-adjusted price deflator for differences between the GDP deflator of each EU country and that of the US. For the second, we adjusted the BEA quality-adjusted price deflator for differences between the business investment deflator of each EU country and that of the US. ${ }^{27}$ Using these harmonized price deflators and the 1995 PPP, current price

\footnotetext{
${ }^{27}$ A non-harmonized price index for the EU countries was also calculated by only using the business investment deflator as this gives the option of comparing the capital stocks using both harmonized and non-harmonized price indices.
} 
investment series were then converted into 1995 constant national prices and 1995 PPP\$. Using PIM with a log-linear retirement pattern, capital stocks are calculated both in 1995 constant national prices and 1995 PPP\$. For hardware an ASL of 3.5 years was used, for software of 1.5 years and for telecom equipment of 7.5 years. ${ }^{28}$ Finally, using the approach as developed in Section 2, the hardware, software and telecom equipment capital stocks are then combined to calculate the aggregate ICT capital stock.

Table 4.3 presents some descriptive statistics for the harmonized and non-harmonized price deflators. For the non-harmonised deflator there are major differences between the EU countries and the US. For all three ICT categories European prices have been increasing over 1990-2000, whereas the US prices have been falling, especially for IT hardware. The table also shows an accelerated price decline in the $2^{\text {nd }}$ half of the 1990s for hardware and telecom equipment in the US, whereas the decline of US software prices has slowed down. The harmonized prices indices show similar results for the EU countries as for the US. The largest price declines are seen for IT hardware, with an accelerated price decline in the $2^{\text {nd }}$ half of the 1990s. For IT software harmonized prices have been falling for 4 EU countries. For all EU countries software prices are no longer falling in the $2^{\text {nd }}$ half of the 1990 s. For telecom equipment prices have been fallen in all countries in the 1990s except Italy. Prices have been falling even faster in the $2^{\text {nd }}$ half of the 1990s, and have ceased to increase for Italy.

Table 4.4 shows some descriptive growth statistics for the ICT capital stocks for both price deflators. As expected, the growth rate for the IT hardware capital stock based on harmonized price deflators exceeds by far that based on non-harmonized prices. One also sees a growth acceleration in the $2^{\text {nd }}$ half of the 1990 s, with average annual growth rising to $38 \%$. For IT software, the growth rates of the 'harmonized' capital stock also increases, but this increase is quite small. For telecom equipment, the 'harmonized' capital stock grows marginally faster, with growth picking up in the $2^{\text {nd }}$ half of the 1990s. The differences between the countries are notable, with average annual growth for Finland, France, Germany and Italy being only $4 \%$ in 1995-2000, as to almost 17\% for Denmark, the Netherlands, the UK and the US. The ICT capital stock based on harmonized price deflators grows almost 1.5 times as fast as that based on non-harmonized prices. Similar as for the hardware and telecom equipment capital stock, average growth accelerates in the $2^{\text {nd }}$ half of the 1990s. Only Germany and Italy witness a slowdown in the growth of the ICT capital stock. For both countries this is caused by a growth slowdown in the underlying software and telecom equipment capital stock. France shows a modest growth increase in the $2^{\text {nd }}$ half of the 1990s. Finland, the Netherlands, the UK and the US see an increase of, on average, about 50\% in their growth rates, and Denmark's growth rate even increases by more than $80 \%$.

Using quality-adjusted prices in the calculations of the various ICT capital stocks clearly closes the gap between the US and the EU countries from $9.2 \%$-points to $4.8 \%$-points. This gap closes most strongly in the $2^{\text {nd }}$ half of the 1990s although the US lead is still significant, with only the Netherlands and the UK being close to the US. Especially for telecom equipment, the EU countries are still lagging far behind with the average growth rate being only half of that of the US in 1995-2000.

${ }^{28}$ These correspond to depreciation rates of respectively $18 \%, 37 \%$ and $9 \%$. 
Table 4.4 Descriptive growth statistics for ICT capital stocks

\begin{tabular}{|c|c|c|c|c|c|c|c|}
\hline \multirow{3}{*}{$\begin{array}{l}\text { IT HARDWARE } \\
\text { DEN }\end{array}$} & \multicolumn{3}{|c|}{ Non-Harmonized Prices } & & \multicolumn{3}{|c|}{ Harmonized Prices } \\
\hline & $1990-2000$ & 1990-1995 & $1995-2000$ & & $1990-2000$ & 1990-1995 & $1995-2000$ \\
\hline & 7.98 & 6.91 & 9.27 & DEN & 28.14 & 20.97 & 36.75 \\
\hline FIN & 10.01 & 7.75 & 12.72 & FIN & 30.97 & 21.62 & 42.20 \\
\hline FRA & 7.43 & 7.25 & 7.64 & FRA & 27.33 & 20.82 & 35.13 \\
\hline GER & 9.91 & 9.86 & 9.96 & GER & 30.53 & 24.59 & 37.65 \\
\hline ITA & 6.81 & 7.18 & 6.35 & ITA & 26.43 & 20.60 & 33.42 \\
\hline NLD & 9.60 & 8.14 & 11.35 & NLD & 30.47 & 22.24 & 40.35 \\
\hline UK & 10.74 & 11.16 & 10.23 & UK & 31.25 & 26.16 & 37.35 \\
\hline US & 32.99 & 26.86 & 40.35 & US & 32.99 & 26.86 & 40.35 \\
\hline \multirow[t]{2}{*}{ Average $^{1}$} & 11.93 & 10.64 & 13.48 & Average $^{1}$ & 29.76 & 22.98 & 37.90 \\
\hline & \multicolumn{3}{|c|}{ Non-Harmonized Prices } & & \multicolumn{3}{|c|}{ Harmonized Prices } \\
\hline IT SOFTWARE & $1990-2000$ & 1990-1995 & $1995-2000$ & & $1990-2000$ & 1990-1995 & $1995-2000$ \\
\hline DEN & 9.73 & 7.56 & 12.33 & DEN & 11.44 & 10.20 & 12.92 \\
\hline FIN & 10.74 & 8.47 & 13.46 & FIN & 12.44 & 11.10 & 14.04 \\
\hline FRA & 11.00 & 10.65 & 11.42 & FRA & 12.74 & 13.36 & 12.00 \\
\hline GER & 11.35 & 11.05 & 11.71 & GER & 13.12 & 13.81 & 12.29 \\
\hline ITA & 7.07 & 7.78 & 6.20 & ITA & 8.76 & 10.41 & 6.77 \\
\hline NLD & 10.25 & 8.88 & 11.90 & NLD & 11.99 & 11.56 & 12.50 \\
\hline UK & 13.18 & 13.27 & 13.08 & UK & 14.95 & 16.07 & 13.61 \\
\hline US & 12.08 & 11.36 & 12.94 & US & 12.08 & 11.36 & 12.94 \\
\hline \multirow[t]{2}{*}{ Average $^{1}$} & 10.67 & 9.88 & 11.63 & Average $^{1}$ & 12.19 & 12.23 & 12.13 \\
\hline & \multicolumn{3}{|c|}{ Non-Harmonized Prices } & & \multicolumn{3}{|c|}{ Harmonized Prices } \\
\hline $\begin{array}{l}\text { TELECOM } \\
\text { EQUIPMENT }\end{array}$ & $1990-2000$ & 1990-1995 & $1995-2000$ & & $1990-2000$ & 1990-1995 & $1995-2000$ \\
\hline DEN & 7.02 & 3.63 & 11.09 & DEN & 8.48 & 4.45 & 13.31 \\
\hline FIN & 5.74 & 5.73 & 5.75 & FIN & 6.98 & 6.63 & 7.41 \\
\hline FRA & 4.69 & 5.50 & 3.72 & FRA & 5.90 & 6.45 & 5.24 \\
\hline GER & 3.85 & 5.66 & 1.68 & GER & 4.93 & 6.53 & 3.02 \\
\hline ITA & 4.70 & 8.09 & 0.62 & ITA & 5.74 & 9.00 & 1.82 \\
\hline NLD & 13.08 & 11.35 & 15.15 & NLD & 14.85 & 12.47 & 17.70 \\
\hline UK & 10.15 & 5.82 & 15.34 & UK & 11.78 & 6.74 & 17.84 \\
\hline US & 13.43 & 9.62 & 18.01 & US & 13.43 & 9.62 & 18.01 \\
\hline \multirow[t]{2}{*}{ Average $^{1}$} & 7.83 & 6.92 & 8.92 & Average $^{1}$ & 9.01 & 7.74 & 10.54 \\
\hline & \multicolumn{3}{|c|}{ Non-Harmonized Prices } & & \multicolumn{3}{|c|}{ Harmonized Prices } \\
\hline ICT & $1990-2000$ & 1990-1995 & $1995-2000$ & & $1990-2000$ & $1990-1995$ & $1995-2000$ \\
\hline DEN & 8.04 & 5.65 & 10.91 & DEN & 13.49 & 9.84 & 17.86 \\
\hline FIN & 7.81 & 6.69 & 9.16 & FIN & 12.38 & 10.15 & 15.06 \\
\hline FRA & 6.69 & 6.88 & 6.46 & FRA & 10.75 & 10.31 & 11.28 \\
\hline GER & 6.10 & 7.03 & 4.97 & GER & 9.25 & 9.55 & 8.89 \\
\hline ITA & 5.33 & 7.90 & 2.24 & ITA & 8.28 & 10.45 & 5.69 \\
\hline NLD & 11.31 & 9.73 & 13.21 & NLD & 16.70 & 14.09 & 19.84 \\
\hline UK & 10.97 & 9.02 & 13.30 & UK & 16.56 & 13.35 & 20.41 \\
\hline US & 17.24 & 13.99 & 21.16 & US & 17.24 & 13.99 & 21.16 \\
\hline Average $^{1}$ & 9.19 & 8.36 & 10.18 & Average $^{1}$ & 13.08 & 11.46 & 15.02 \\
\hline "EU" - US & -9.21 & -6.43 & -12.55 & "EU" - US & -4.76 & -2.88 & -7.01 \\
\hline
\end{tabular}

${ }^{1}$ Arithmetic average 


\section{Contribution of various inputs in labour productivity growth and output growth}

The contribution of various input factors to output growth is already defined in equation (2.3), where the growth rate of $A$, the level of technology, is defined as Total Factor Productivity growth (TFP). This factor can, as usual, be computed as a residual. Labour productivity growth (ALP) can easily be obtained as the residual between the rates of output growth and average annual hours worked. Assuming constant returns to scale in capital and labour, TFP growth can then be calculated as the difference between labour productivity growth and the growth rate of the aggregate capital stock. So the contributions to output growth are calculated according to:

$$
\hat{Y}=\hat{A}+\sum_{j} \bar{v}_{k j} \cdot \hat{K}_{j}+\bar{v}_{h} \cdot \hat{H}
$$

where $\hat{A}$ denotes the growth rate of TFP, which is calculated as a residual. The basic assumption employed is that both firm behaviour and well functioning factor markets assure that all factors are paid their marginal product. Dividing (5.1) by the amount of labour input gives a similar equation in terms of labour productivity:

$$
\hat{y}=\hat{A}+\sum_{j} \bar{v}_{k j} \cdot \hat{k}_{j}
$$

where $y$ denotes labour productivity $(\mathrm{Y} / \mathrm{H})$ and $k$ denotes capital intensity $(\mathrm{K} / \mathrm{H})$. (5.2) follows directly from (5.1) under the assumption that all income shares add up to one. Note that in both cases the TFP growth term is exactly the same, so both ways lead to the same value of TFP growth.

As explained in Section 3.3, R\&D expenditures, which are not treated as investments in the SNA, are also to be included in the knowledge-based capital stock. However, as these expenditures are treated as intermediary consumption and not as final output in the current SNA, enlarging the concept of the knowledge-based capital stock by including all R\&D expenditures as investments, requires us to also enlarge the concept of output, i.e. value added, as all investments are accounted for as final output. Disregarding the capital expenditures part of BERD, which should already be accounted for as investment ${ }^{29}$, this would simply mean adding BERD to the value of domestic product of industry (DPI). In 1995 constant prices, adding BERD to DPI will increase DPI by on average $1.75 \%$ for all countries, ranging from $0.8 \%$ for Italy to $2.3 \%$ for Finland and the US. In our calculations we started from the assumption that for all countries the value added in constant prices is computed using Paasche price chain indices, i.e. using Laspeyres volume chain indices. This is common practise in the SNA. We employed the same method to include $\mathrm{R} \& \mathrm{D}$ expenditures, which are now treated as investments, in the value-added figures.

Output growth rates and the contributions from IT hardware, IT software, Telecom equipment, R\&D, Other capital, TFP and Hours worked are presented in Table 5.1, for nonharmonized and harmonized prices. Non-harmonized output growth for 1990-2000 was highest in the US, followed closely by the Netherlands. The US lead is due to its growth acceleration in 1995-2000. In the $1^{\text {st }}$ half of the 1990s the US was even lagging behind

\footnotetext{
${ }^{29}$ Section 5 in Meijers and Hollanders (2002b) shows that excluding BERD capital expenditures does not influence the growth results as shown in Tables 4.1 and 4.2 in a significant way.
} 
Germany and the Netherlands, but by almost doubling its growth rate it surpassed these countries to become the overall growth leader. Only Finland showed a higher growth rate in 1995-2000, but due to a declining economy in 1990-1995, overall Finnish growth performance was only ahead of that in France, Italy and the UK. The growth contribution from IT hardware for the EU countries is far below that for the US, for a large part due to the use of quality-adjusted hardware prices in the US. The growth contribution of TFP was highest in Finland, being almost twice as high as in the $2^{\text {nd }}$ best performing country. Hours worked contributed significantly to output growth in both the Netherlands and the US, indicating that employment in terms of total hours worked increased considerable in both countries. The growth contribution of R\&D was highest in Finland, most notably in 19952000.

Using harmonized prices, on average output growth has increased in all EU countries by 0.16 $\%$-points in 1990-2000 and 0.19\%-points in 1995-2000. But even after allowing for qualityadjusted prices, the US is still the leader in output growth, although Dutch growth performance is clearly challenging this position. Except for Germany, all countries show an increase in growth performance in the $2^{\text {nd }}$ half of the $1990 \mathrm{~s}$, with the biggest increase for Finland. Growth contributions from the various ICT capital components show similar results. The growth contribution from IT hardware has increased in all countries, and is close to the US level in Denmark and the UK. The relative biggest increases are seen in France and Italy, although Italy is still lagging furthest behind. The growth contributions from IT software and Telecom equipment have increased, but relatively less, in all countries. Growth contributions from R\&D, other capital and TFP are only increasing marginally. ${ }^{30}$

Table 5.1 Contributions to Output Growth

\begin{tabular}{|c|c|c|c|c|c|c|c|c|c|}
\hline \multirow{5}{*}{$\begin{array}{l}\text { Growth of } \\
\text { Output }\end{array}$} & & \multicolumn{8}{|c|}{ Non-Harmonized Prices } \\
\hline & & DEN & FIN & FRA & GER & ITA & NLD & UK & US \\
\hline & $1990-2000$ & 2.61 & 2.42 & 1.98 & 2.45 & 1.80 & 3.19 & 2.39 & 3.46 \\
\hline & 1990-1995 & 2.19 & -0.57 & 1.31 & 2.73 & 1.51 & 2.57 & 1.83 & 2.46 \\
\hline & $1995-2000$ & 3.15 & 5.73 & 2.68 & 2.11 & 2.34 & 3.71 & 3.07 & 4.40 \\
\hline \multirow{4}{*}{ IT Hardware } & \multicolumn{9}{|c|}{ Contribution (percentage points from): } \\
\hline & $1990-2000$ & 0.07 & 0.07 & 0.04 & 0.05 & 0.03 & 0.06 & 0.08 & 0.26 \\
\hline & 1990-1995 & 0.06 & 0.05 & 0.04 & 0.04 & 0.03 & 0.05 & 0.08 & 0.18 \\
\hline & $1995-2000$ & 0.08 & 0.09 & 0.04 & 0.05 & 0.02 & 0.07 & 0.09 & 0.34 \\
\hline \multirow[t]{3}{*}{ IT Software } & $1990-2000$ & 0.15 & 0.11 & 0.12 & 0.10 & 0.04 & 0.14 & 0.15 & 0.16 \\
\hline & 1990-1995 & 0.11 & 0.09 & 0.10 & 0.09 & 0.04 & 0.12 & 0.13 & 0.22 \\
\hline & $1995-2000$ & 0.18 & 0.14 & 0.13 & 0.11 & 0.03 & 0.16 & 0.16 & 0.11 \\
\hline \multirow{3}{*}{$\begin{array}{l}\text { Telecom } \\
\text { Equipment }\end{array}$} & $1990-2000$ & 0.06 & 0.07 & 0.05 & 0.06 & 0.07 & 0.09 & 0.08 & 0.10 \\
\hline & 1990-1995 & 0.04 & 0.07 & 0.06 & 0.08 & 0.12 & 0.08 & 0.05 & 0.07 \\
\hline & $1995-2000$ & 0.07 & 0.05 & 0.04 & 0.02 & 0.01 & 0.09 & 0.11 & 0.14 \\
\hline \multirow[t]{3}{*}{$\mathrm{R} \& \mathrm{D}$} & $1990-2000$ & 0.10 & 0.16 & 0.07 & 0.05 & 0.01 & 0.03 & 0.02 & 0.08 \\
\hline & 1990-1995 & 0.09 & 0.11 & 0.09 & 0.05 & 0.03 & 0.02 & 0.03 & 0.06 \\
\hline & $1995-2000$ & 0.10 & 0.19 & 0.04 & 0.03 & 0.00 & 0.05 & 0.02 & 0.08 \\
\hline
\end{tabular}

\footnotetext{
${ }^{30}$ The reported growth contributions are close to those found by Colecchia and Schreyer (2001) for Finland, France, Germany, Italy, the UK and the US. As the latter do not distinguish between hardware and telecom equipment, the results in Table 4.1 for these two have to be added. For France and the UK the results are almost identical, for the other countries Colecchia and Schreyer find a higher growth contribution, partly due to the fact that they use national estimates for ICT investments as opposed to the WITSA/IDC based Eurostat data in this study. Growth contributions from software as reported by Colecchia and Schreyer are higher for Finland, Italy and the US, and lower for the UK.
} 


\begin{tabular}{|c|c|c|c|c|c|c|c|c|c|}
\hline \multirow[t]{3}{*}{ Other capital } & $1990-2000$ & 0.64 & 0.01 & 0.81 & 0.72 & 0.84 & 0.61 & 0.51 & 0.49 \\
\hline & 1990-1995 & 0.56 & 0.06 & 0.92 & 0.81 & 0.67 & 0.50 & 0.51 & 0.25 \\
\hline & $1995-2000$ & 0.71 & -0.09 & 0.67 & 0.62 & 0.99 & 0.70 & 0.50 & 0.73 \\
\hline \multirow{3}{*}{$\begin{array}{l}\text { Total Factor } \\
\text { Productivity }\end{array}$} & $1990-2000$ & 1.53 & 2.89 & 0.75 & 1.42 & 0.84 & 1.33 & 1.07 & 1.29 \\
\hline & 1990-1995 & 1.67 & 1.79 & 0.51 & 1.99 & 1.20 & 1.51 & 1.20 & 0.83 \\
\hline & $1995-2000$ & 1.25 & 4.08 & 0.93 & 1.06 & 0.74 & 1.11 & 0.89 & 1.61 \\
\hline \multirow{5}{*}{$\begin{array}{l}\text { Hours } \\
\text { Worked }\end{array}$} & $1990-2000$ & 0.06 & -0.89 & 0.15 & 0.06 & -0.02 & 0.92 & 0.46 & 1.06 \\
\hline & 1990-1995 & -0.35 & -2.75 & -0.40 & -0.34 & -0.58 & 0.30 & -0.18 & 0.85 \\
\hline & $1995-2000$ & 0.77 & 1.27 & 0.82 & 0.21 & 0.55 & 1.53 & 1.31 & 1.39 \\
\hline & & \multicolumn{8}{|c|}{ Harmonized Prices } \\
\hline & & DEN & FIN & FRA & GER & ITA & NLD & UK & US \\
\hline \multirow{4}{*}{$\begin{array}{l}\text { Growth of } \\
\text { Output }\end{array}$} & $1990-2000$ & 2.81 & 2.60 & 2.11 & 2.57 & 1.89 & 3.37 & 2.58 & 3.46 \\
\hline & $1990-1995$ & 2.34 & -0.45 & 1.41 & 2.83 & 1.59 & 2.70 & 1.96 & 2.46 \\
\hline & $1995-2000$ & 3.40 & 5.96 & 2.83 & 2.26 & 2.45 & 3.93 & 3.31 & 4.40 \\
\hline & \multicolumn{9}{|c|}{ Contribution (percentage points from): } \\
\hline \multirow[t]{3}{*}{ IT Hardware } & $1990-2000$ & 0.25 & 0.23 & 0.15 & 0.15 & 0.10 & 0.21 & 0.24 & 0.26 \\
\hline & $1990-1995$ & 0.17 & 0.14 & 0.12 & 0.10 & 0.08 & 0.14 & 0.17 & 0.18 \\
\hline & $1995-2000$ & 0.32 & 0.30 & 0.18 & 0.18 & 0.12 & 0.27 & 0.29 & 0.34 \\
\hline \multirow[t]{3}{*}{ IT Software } & $1990-2000$ & 0.17 & 0.13 & 0.14 & 0.12 & 0.06 & 0.17 & 0.17 & 0.16 \\
\hline & 1990-1995 & 0.23 & 0.17 & 0.18 & 0.16 & 0.08 & 0.23 & 0.24 & 0.22 \\
\hline & $1995-2000$ & 0.11 & 0.09 & 0.09 & 0.07 & 0.02 & 0.10 & 0.11 & 0.11 \\
\hline \multirow{3}{*}{$\begin{array}{l}\text { Telecom } \\
\text { Equipment }\end{array}$} & $1990-2000$ & 0.07 & 0.08 & 0.06 & 0.07 & 0.08 & 0.10 & 0.10 & 0.10 \\
\hline & 1990-1995 & 0.04 & 0.09 & 0.07 & 0.10 & 0.13 & 0.09 & 0.06 & 0.07 \\
\hline & $1995-2000$ & 0.09 & 0.07 & 0.05 & 0.04 & 0.02 & 0.12 & 0.13 & 0.14 \\
\hline \multirow[t]{3}{*}{$\mathrm{R} \& \mathrm{D}$} & $1990-2000$ & 0.10 & 0.16 & 0.07 & 0.05 & 0.01 & 0.03 & 0.02 & 0.08 \\
\hline & 1990-1995 & 0.09 & 0.11 & 0.09 & 0.05 & 0.03 & 0.02 & 0.03 & 0.06 \\
\hline & $1995-2000$ & 0.10 & 0.19 & 0.04 & 0.03 & 0.00 & 0.05 & 0.02 & 0.08 \\
\hline \multirow[t]{3}{*}{ Other capital } & $1990-2000$ & 0.64 & 0.01 & 0.80 & 0.72 & 0.83 & 0.61 & 0.51 & 0.49 \\
\hline & 1990-1995 & 0.55 & 0.06 & 0.90 & 0.80 & 0.66 & 0.49 & 0.50 & 0.25 \\
\hline & $1995-2000$ & 0.72 & -0.09 & 0.68 & 0.63 & 0.99 & 0.71 & 0.51 & 0.73 \\
\hline \multirow{3}{*}{$\begin{array}{l}\text { Total Factor } \\
\text { Productivity }\end{array}$} & $1990-2000$ & 1.52 & 2.88 & 0.74 & 1.42 & 0.83 & 1.33 & 1.06 & 1.29 \\
\hline & 1990-1995 & 1.61 & 1.74 & 0.46 & 1.95 & 1.18 & 1.44 & 1.14 & 0.83 \\
\hline & $1995-2000$ & 1.29 & 4.12 & 0.96 & 1.10 & 0.74 & 1.16 & 0.94 & 1.61 \\
\hline \multirow{3}{*}{$\begin{array}{l}\text { Hours } \\
\text { Worked }\end{array}$} & $1990-2000$ & 0.06 & -0.89 & 0.15 & 0.06 & -0.02 & 0.92 & 0.46 & 1.06 \\
\hline & 1990-1995 & -0.35 & -2.75 & -0.40 & -0.34 & -0.58 & 0.30 & -0.18 & 0.85 \\
\hline & $1995-2000$ & 0.77 & 1.27 & 0.82 & 0.21 & 0.55 & 1.53 & 1.31 & 1.39 \\
\hline
\end{tabular}

Table 5.2 gives, in a similar way, growth rates for labour productivity and the growth contributions from the various input factors. We see that for those countries having high growth rates for annual hours worked, growth of labour productivity is well below that of output. Both for the Netherlands and the US labour productivity growth is about half that of output growth. For non-harmonized prices, labour productivity growth is highest in Finland, both for 1990-2000 and for both the $1^{\text {st }}$ and $2^{\text {nd }}$ half of this time period. The contribution from IT hardware is once again by far highest in the US, and that of TFP in Finland. 
Table 5.2 Contributions to Labour Productivity Growth

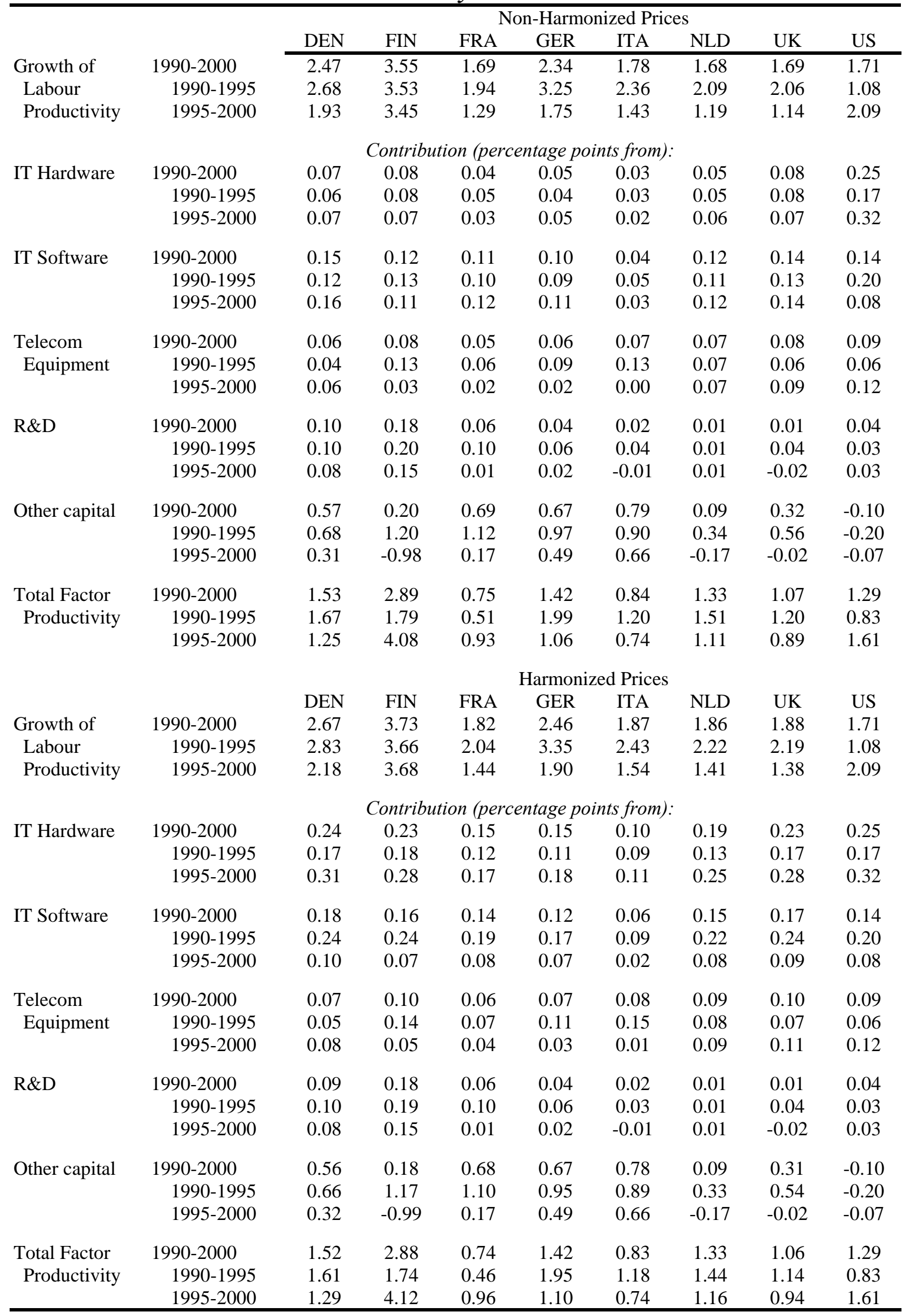


Taking into account quality-adjusted prices increases labour productivity growth by $0.16 \%$ points on average for 1990-2000. Noteworthy is that labour productivity growth slowed down for almost all EU countries Finland from the $1^{\text {st }}$ to the $2^{\text {nd }}$ half of the 1990s. Only for the US growth accelerated. The growth contribution from IT hardware in the EU countries is now once again more in line with that found for the US. For software and telecom equipment contributions to labour productivity growth have increased, for other capital and TFP growth contributions have decreased and for R\&D they are more or less the same.

The traditional factors as hours worked, other capital and TFP are still the factors explaining the largest part of output growth. Furthermore, it seems that these traditional factors are also explaining the uptake in output growth as witnessed in almost all EU countries, as the growth contribution from the various knowledge investments does not increase for the EU countries $^{31}$. For most countries, and especially for Finland, TFP is still explaining a large part of output growth. If one would adopt the opinion that TFP is just a measure for our ignorance of the factors underlying the growth process, it would seem that there is still ample room for improving our understanding of this growth process, notwithstanding the improvements due to using quality-adjusted prices to do justice to the special character of ICT capital goods.

\section{Conclusions}

\subsection{Quality-adjusted prices}

Innovations, both resulting in new products and quality improvements of existing products and services, are at the heart of economic progress by increasing productivity growth. For many years however, quality improvements in many products have either not been measured or were underestimated. Esp. for so-called intangibles, it has proven very difficult to measure these quality changes. As a result, inflation has been overestimated and economic growth has been underestimated. Measuring quality improvements is also a key condition in interpreting and explaining the contribution of individual products and services to economic and productivity growth, particularly to the recent recovery of the Western economies.

The two main techniques for correcting price changes for quality changes are the matchedmodel approach and the hedonic regression approach. The first approach has been used for quite some time and is applied by many countries. The second approach however, which shows much stronger price declines, has only been used quite recently and only in a few countries. Esp. the US has calculated quality-adjusted prices for a diverse range of products to update their CPI. Most notably is the price index for computer hardware, which, as opposed to a general annual price increase of 4 percent over the past 50 years, shows an annual decrease of 17 percent. Mainly spurred by rapidly falling prices for semiconductors (Jorgenson, 2001), these declining real computer prices are held responsible by many for the recent resurgence in (US) growth.

Opposed to the vast number of studies on quality-adjusted prices for computer hardware, only few attempts have been made to do so for computer software. Until the first half of the 1990s this seemed to be a minor problem, as software expenditures were not accounted for as investments in the national accounts. But with the revision of the SNA these expenditures, given certain conditions, also classify as investments. A small number of countries have

\footnotetext{
${ }^{31}$ For the US however, the growth contribution of knowledge investment does increase.
} 
followed these guidelines and publish data on investments in software in current prices. But for growth accounting exercises and for comparing the development of these investments over time with other intangible and tangible assets, time series in constant prices are needed. An even smaller sub sample of countries publish constant price data, but almost all do not take into account the effect of quality changes in software on their prices. The US is the major exception with a time series on quality-adjusted price indexes starting in 1959 for a period of almost 40 years (Parker and Grimm, 2000).

But it is only for pre-packaged software that such a time series has been developed. For ownaccount and custom software indirect price indexes have been calculated, by relating ownaccount software price indexes to wage developments of programmers and system analysts and costs of intermediate inputs and custom software price indexes to a weighted average of those of pre-packaged and business own-account price indexes ( 25 percent respectively 75 percent).

The building blocks for pre-packaged software were laid by a study using matched-model indexes by Oliner and Sichel (1994) and two studies using hedonic price indexes by Gandal (1994) and Brynjolfsson and Kemerer (1996). The results of the last two were repeated, confirmed and updated by McCahill (1997). Gandal and Brynjolfsson and Kemerer both used the hedonic regression technique to estimate quality-adjusted price changes for spreadsheet software between 1986 and 1992. Their results show that these prices decreased on average by 15 to 16 percent per year. The approach followed seems simple, as they collected yearly list prices for spreadsheet programs and data on a whole range of product characteristics, almost all being dummy variables which were assigned a value 1 if the product had the described feature and a value 0 if not. Regressing the price data on these characteristics and time dummies for each year after the base year, allowed them to control for quality changes and thus estimate yearly quality-adjusted or pure price changes.

Parker and Grimm (2000) used both the matched-model results by Oliner and Sichel and the hedonic regression approach outlined in Gandal and Brynjolfsson and Kemerer to construct quality-adjusted price indexes for pre-packaged software for 1959-1998. Their results show that these declined by 10 percent per year, not only a strong decline and in sharp contrast with the overall increase of the GDP deflator by 4 percent per year, but also not that far below the reported 17 percent annual price decline for computer hardware by Jorgenson (2001).

Given these results, a straight-forward question would be why other countries do not apply these techniques, in particular the hedonic regression technique, to construct quality-adjusted price series for software investments. Aside from the theoretical problems dealing with the influence of network effects which limit the choice set of consumers, ${ }^{32}$ the assumption of competitive markets, ${ }^{33}$ and how to deal with those products whose quality changes rapidly

\footnotetext{
${ }^{32}$ If a marginal consumer has to choose between two software packages of which one is used by 90 percent of the computer users and the other by only 10 percent, then for reasons of compatibility one is likely to choose for the product best diffused even if the other product is the better one from a technological point of view.

${ }^{33}$ One underlying assumption of the hedonic approach is that changes in prices are either due to changes in product characteristics or due to general price changes. This assumes a more or less competitive market, and esp. in the computer and software market, the market structure can be better characterized as an oligopoly or sometimes even a monopoly, in which producers can set prices and introduce price changes which are not related at all with changes in quality.
} 
over time. ${ }^{34}$ Even being far from perfect, the hedonic approach is still the preferred one due to a lack of better alternatives.

Why then do not more countries apply this technique? The answer is as simple as it is depressing: due to a lack of data and, to a lesser extent, to the subjective nature of determining which product characteristics are important and which are not. For word processing software, McCahill (1997) showed that there are 341 possible product characteristics for this type of software, of which he could only use 45 , partly due to data constraints and partly due to the fact that most did not show up significantly in his first-round 'investigative' regressions. Maybe determining which characteristics are important by checking if they show up significantly in an econometric regression is already questionable, but the alternative of asking so-called experts or software users is even less attractive as their answers are prone to generate even more difficulties of subjectivity. But even if one were able to determine these characteristics in a non-disputed way, one would then without doubt be faced by the depressing fact that there is either no data available for many of these characteristics, or that the data which are available are incomplete and inconsistent over time, not only between countries but also within countries, partly caused by the fact that the sources of these data are private sources.

Furthermore, one should keep in mind that the available studies using hedonic price indexes are all on pre-packaged software, software which is intended for nonspecialized uses and which is sold or licensed in standardized form. If it is already difficult to identify product characteristics for this kind of software, it will be even more difficult to find a set of common characteristics for custom and own-account software, as these are tailored to the needs of the business or government unit which is going to use this software. Even within the same business unit, different versions of in-house developed software, may be so dissimilar that there are likely to be almost no common product characteristics. And if it is already difficult to determine common characteristics for custom and own-account software, it will be even more difficult, not to say almost impossible, to find the necessary data to use as an input in the hedonic price regressions.

\subsection{Sources of growth}

Investments in intangibles have grown faster than those in tangibles in the last decades of the $20^{\text {th }}$ century and, especially for the US, the contribution of the corresponding intangible capital stocks to output and productivity growth has increased in the 1990s and especially in the $2^{\text {nd }}$ half of that decade. European growth has been reported to be increasingly lagging behind this accelerating US growth. One explanation offered in this study and by others (e.g. Daveri (2000), Schreyer (2000) and Colecchia and Schreyer (2001)), is that the use by the US of hedonic or quality-adjusted prices for investments in information and communication technologies (ICT) has biased the picture in favour of the US.

Following the approach introduced by Schreyer (2000), we have constructed harmonized price deflators for investments in IT hardware, IT software and Telecommunication equipment to derive constant price investments in these ICT components. As these investments are, in principal, already accounted for as such in the SNA, current price output

\footnotetext{
${ }^{34}$ A concern expressed by a.o. Parker and Grimm (2000), who choose deliberately for a weighted average of matched-model price indexes and hedonic price indexes because "the hedonic index may overstate price declines because over time, the characteristics of high-priced packages with limited sales are incorporated into lower priced packages that have much greater sales".
} 
does not change. In the SNA R\&D expenditures are not included in output, except for R\&D sold on contract. Classifying these expenditures as (knowledge) investments increases current price output by $1.75 \%$ on average. Output in constant prices will change both as a result of the use of quality-adjusted prices for ICT investments and of the re-classification of R\&D expenditures as investments.

The introduction of harmonized prices for the seven EU countries studied decreases the gap in growth performance between these EU countries and the US. The average gap of $1.06 \%$ points for 1990-2000 was reduced to 0.90, with the largest decrease for Denmark and the smallest decrease for Italy. Growth performance of the Netherlands is closest to that of the US with a remaining gap of only $0.10 \%$-points. The growth acceleration of the US in the $2^{\text {nd }}$ half of the 1990s increased the gap in 1995-2000, although it is considerably less than when non-harmonized prices are used for the ICT investments. Only Finland showed a growth rate even higher than that of the US, but this is in all likelihood the result of a recovery of the serious recession in the early nineties in that country.

Growth performance and contributions to growth from the various capital components is quite different among the European countries, Germany even experienced a decline in output growth in the $2^{\text {nd }}$ half of the 1990s. For Finland, total factor productivity growth was by far the main contributor to output growth, especially in 1995-2000. For the Netherlands and the UK almost 40 percent of output growth was coming from strong increases in the volume of employment. For Italy non-knowledge capital services are the main contributor to output growth. The highest contributions from ICT capital services, with more than 15 percent of output growth, are seen in Denmark and the UK. Noteworthy is that growth contributions from hardware and telecom equipment capital services have increased in the $2^{\text {nd }}$ half of the 1990s whereas that from software capital services has strongly decreased.

Our main conclusions are that in order to compare the growth performance of the US and the EU countries:

- ICT investments and ICT prices should be measured on a consistent and comparable basis, thus using hedonic or quality-adjusted prices. Such prices should also be developed for all (European) countries and special attention should be paid to individual categories such as custom and own-account production of software and the output from R\&D since quality is hard to measure in these categories;

- ICT and R\&D investments should be seen as knowledge investments. In this respect, the difference between tangibles and intangibles is less important and a distinction between knowledge capital and other capital is more relevant. There is a considerable overlap of intangibles and knowledge capital, however;

- Both R\&D and ICT are subject to spillovers such that their impact on output and productivity growth is not restricted to the direct (production) effect. This also implies that the social returns exceed the private returns such that profound economic policy is essential for optimal knowledge accumulation.

Due to both the direct and indirect contributions to growth, investments in knowledge are shown to be important and, as the second half of the 1990s has shown, might even become more important in the future. Further research however is needed, both to the underlying mechanisms and in the more basic aspects of how to measure these investments, both in current and in quality-adjusted constant prices and implementation of current a new insights is crucial in this respect. This will also put the growth difference between the US and Europe in another perspective. 


\section{References}

Abraham, Katherine G., John S. Greenless and Brent R. Moulton, Working to Improve the Consumer Price Index, Journal of Economic Perspectives, Vol. 12: 27-36, 1998.

Abramovitz, M. and P. David, Convergence and Deferred Catch-Up, in R. Landau, T. Taylor and G. Wright (eds.), The Mosaic of Economic Growth, Stanford University Press: 21-62, 1996.

Adelman, Irma and Zvi Griliches, On an Index of Quality Change, Journal of the American Statistical Association, Vol. 56: 535-548, 1961.

Aizcorbe, Ana, Carol Corrado and Mark Doms, Constructing Price and Quantity Indexes for High Technology Goods, paper presented at the NBER Summer Institute 2000 session on Price, Output and Productivity Measurement, July 2000.

Anxo, D. and A. Bigsten, Working Hours and Productivity in Swedish Manufacturing, Scandinavian Journal of Economics, Vol. 91: 613-19, 1989.

Berndt, Ernst R., Ellen R. Dulberger and Neal J. Rappaport, Price and Quality of Desktop and Mobile Personal Computers: A Quarter Century of History, paper presented at the NBER Summer Institute 2000 session on Price, Output and Productivity Measurement, July 2000.

Berndt, Ernst R. and Zvi Griliches, Price Indexes for Microcomputers: An Exploratory Study, in: M.F. Foss, M.E. Manser and A.H, Young (eds.), Price Measurements and Their Uses, Studies in Income and Wealth, NBER, Chicago University Press, 1993.

Berndt, Ernst R., Zvi Griliches and Neal J. Rappaport, Econometric Estimates of Price Indexes for Personal Computers in the 1990s, Journal of Econometrics, Vol. 68: 243-268, 1995.

Berndt, Ernst R. and Neal J. Rappaport, Price and Quality of Desktop and Mobile Personal Computers: A Quarter-Century Historical Overview, American Economic Review Papers and Proceedings, Vol. 91: 268-273, 2001.

Bode, Ben and Jan van Dalen, Quality-corrected price indexes of new passenger cars in the Netherlands, 1990-1999, Statistics Netherlands, March 2001.

Boskin, Michael J., Ellen R. Dulberger, Robert J. Gordon, Zvi Griliches and Dale W. Jorgenson, Consumer Prices, the Consumer Price Index, and the Cost of Living, Journal of Economic Perspectives, Vol. 12: 3-26, 1998.

Brynjolfsson, E. and L. Hitt, Beyond Computation: Information Technology, Organizational Transformation and Business Performance, Journal of Economic Perspectives, Vol. 14: 23-48, 2000.

Brynjolfsson, E., L. Hitt and S. Yang, Intangible Assets: How the Interaction of Computers and Organizational Structure Affects Stock Market Valuations, MIT Working paper, 2000.

Brynjolfsson, Erik and Chris F. Kemerer, Network Externalities in Microcomputer Software: An Econometric Analysis of the Spreadsheet Market, Management Science, Vol. 42: 1627-1647, December 1996.

Cartwright, David W., Improved Deflation of Purchases of Computers, Survey of Current Business, Vol. 66: 7-9, March 1986.

Chow, Gregory C., Technological Change and the Demand for Computers, American Economic Review, Vol. 57: 1117-1130, December 1967.

Chwelos, Paul, Hedonic Approaches to Measuring Price and Quality Change in Personal Computer Systems, University of British Columbia, unpublished PhD thesis, December 1999.

Cohen, Jeremy M., Rapid change in the Personal Computer Market: A Quality-Adjusted Hedonic Price Index, 1976-1987, Massachusetts Institute of Technology, Sloan School of Management, unpublished S.M. thesis, May 1988.

Cole, Rosanne, Y.C. Chen, Joan A. Barquin-Stolleman, Ellen R. Dulberger, Nurhan Helvacian and James H. Hodge, Quality-Adjusted Price Indexes for Computer Processors and Selected Peripheral Equipment, Survey of Current Business, Vol. 66: 41-50, January 1986.

Colecchia, A. and P. Schreyer, ICT Investment and Economic Growth in the 1990s: Is the United States a Unique Case? A Comparative Study of Nine OECD Countries, OECD STI Working Paper 2001-7, 2001.

Croes, M.M., Data for Intangibles in Selected OECD countries, Statistics Netherlands, December 2000. 
Daveri, F., Is Growth an Information Technology Story in Europe too?, IGIER (Innocenzo Gasparini Institute for Economic Research) Working Paper 168, 2000.

Deaton, Angus, Getting Prices Right: What Should be Done?, Journal of Economic Perspectives, Vol. 12: $37-46,1998$

Diewert, E., Aggregation Problems in the Measurement of Capital, in: D. Usher (ed.), The Measurement of Capital, Chicago, University of Chicago Press: 433-528, 1980.

Diewert, Erwin, Index Number Issues in the Consumer Price index, Journal of Economic Perspectives, Vol. 12: 47-58, 1998.

Dulberger, E., The Application of a Hedonic Model to a Quality-Adjusted Price Index for Computer Processors, in: Dale Jorgenson and Ralph Landau (eds.), Technology and Capital Formation, MIT Press, 1989.

Fosgerau, M., S. E. Hovgaard Jensen and A. Sørensen, Measuring Educational Heterogeneity and Labour Quality: A Note, CEBR Discussion paper 2001-6, 2000.

Gandal, Neil, Hedonic Price Indexes for Spreadsheets and an Empirical Test for Network Externalities, RAND Journal of Economics, Vol. 25: 160-170, Spring 1994.

Gordon, R., The Postwar Evolution of Computer Prices, in: Dale Jorgenson and Ralph Landau (eds.), Technology and Capital Formation, MIT Press, 1989.

Griliches, Zvi, R\&D and the Productivity Slowdown, American Economic Review, Vol. 70: 343-348, 1980.

Griliches, Zvi, $R \& D$ and productivity, the econometric evidence, Chicago, University of Chicago Press, 1998.

Griliches, Zvi (ed.), Price Indexes and Quality Change: Studies in New Methods of Measurement, Harvard University Press: Cambridge, Massachusetts, 1971.

Griliches, Zvi, Hedonic Price Indexes for Automobiles: An Econometric Analysis of Quality Change, in: The Price Statistics of the Federal Government, Vol .73: 137-196, NBER: New York, 1961 (reprinted in Griliches, 1971).

Hausman, Jerry, Sources of Bias and Solutions to Bias in the Consumer Price Index, Journal of Economic Perspectives, 17(1), 2003, pp. 23-44.

Ho, M. and D. W. Jorgenson, The Quality of the U.S. Workforce, 1958-95, Harvard University, 1999.

Hollanders, H. and H. Meijers, Quality-Adjusted Prices and Software Investments: the Use of Hedonic Price Indexes, MERIT/Infonomics, 2002. http://www.researchineurope.org/newkind/Documentation/PDF/2v_D2b_Ann2_snt.pdf

ILO (International Labour Organization), Revision of the ILO Manual on CPI, 2001.

Jorgenson, Dale W., Capital Theory and Investment Behavior, American Economic Review, Vol. 53: 247-259, 1963.

Jorgenson, Dale W. and K. J. Stiroh, Raising the Speed Limit: U.S. Economic Growth in the Information Age, Harvard University and Federal Reserve Bank of New York, 2000.

Jorgenson, Dale W., Information Technology and the U.S. Economy, American Economic Review, Vol. 91: 1-32, March 2001.

Kim, Amy Y., Hedonic Price Indices and an Examination of the Personal Computer Market, Harvard College, unpublished honors undergraduate thesis, March 1989.

Kokoski, Mary, Keith Waehrer and Patricia Rozaklis, Using Hedonic Methods for Quality Adjustment in the CPI: The Consumer Audio Products Component, BLS Working Paper 344, 2001. http://www.bls.gov/ore/pdf/ec010120.pdf

Landefeld, Steven J. and Bruce T. Grimm, A Note on the Impact of Hedonics and Computers on Real GDP, Survey of Current Business, Vol. 80: 17-22, December 2000.

Leslie, D., The Productivity of Hours in U.S. Manufacturing Industries, Review of Economics and Statistics, Vol. 66: 486-90, 1984.

Liegey, Paul, Developing a Hedonic Regression Model For DVD Players In the U.S. CPI, BLS draft paper. http://www.bls.gov/cpi/cpidvd.htm

Liegey, Paul, Hedonic Quality Adjustment Methods for Clothes Dryers In the U.S. CPI, BLS draft paper. http://www.bls.gov/cpi/cpidryer.htm

Liegey, Paul, Hedonic Quality Adjustment Methods for Microwave Ovens In the U.S. CPI, BLS draft paper. http://www.bls.gov/cpi/cpimwo.htm 
McCahill, Robert John, A Hedonic Study of Prepackaged Software, Virginia Polytechnic Institute and State University, unpublished Master of Arts thesis, May 1997.

Meijers, H. and H. Hollanders, Sources of Growth in the Knowledge Based Economy: The Role of R\&D and ICT in Europe and the US, MERIT/Infonomics, 2002. http://www.researchineurope.org/newkind/Documentation/PDF/1V_D5Ann4_snt.pdf

Nelson, Randy A., Tim L. Tanguay and Christopher D. Patterson, A Quality-Adjusted Price Index for Personal Computers, Journal of Business and Economic Statistics, Vol. 12: 23-31, January 1994.

Nonaka, I. and H. Takeuchi, The Knowledge-Creating Company, New York, Oxford University Press, 1995.

Nordhaus, William D., Quality Changes in Price Indexes, Journal of Economic Perspectives, Vol. 12: 59-68, 1998.

OECD, Measuring Capital: A Manual on the Measurement of Capital Stocks, Consumption of Fixed Capital and Capital Services, 2000.

OECD, OECD Productivity Manual: A Guide to the Measurement of Industry-level and Aggregate Productivity Growth, 2001.

Oliner, Stephen D. and Daniel E. Sichel, Computers and Output Growth Revisited: How Big is the Puzzle, Brookings Papers on Economic Activity, Vol. 2: 273-334, 1994.

Oliner, Stephen D. and Daniel E. Sichel, The Resurgence of Growth in the Late 1990s: Is Information Technology the Story?, Journal of Economic Perspectives, Vol. 14: 3-22, Fall 2000.

Parker and Grimm, Recognition of Business and Government Expenditures for Software as Investment: Methodology and Quantitative Impacts, 1959-98, Bureau of Economic Analysis, May 2000.

Pollak, Robert A., The Consumer Price Index: A Research Agenda and Three Proposals, Journal of Economic Perspectives, Vol. 12: 69-78, 1998.

Raa, ten T. and E. Wolff, Engines of Growth in the US Economy, Structural Change and Economic Dynamics, Vol.11: 473-489, 2000.

Reese, Mike, Hedonic Quality Adjustment Methods for College Textbooks In the U.S. CPI, BLS draft paper. http://www.bls.gov/cpi/cpictb.htm

Schreyer, Paul, The Contribution of Information and Communication Technology to Output Growth: a Study of the G7 Countries, STI Working Paper 2000/2, OECD: Paris, 2000.

Shapiro, Matthew D. and David W. Wilcox, Mismeasurement in the Consumer Price Index: An Evaluation, in: Ben S. Bernanke and Julio Rotemberg (eds.), NBER Macroeconomics Annual 1996, MIT Press, 1996.

Shepler, Nicole, Developing a Hedonic Regression Model For Camcorders In the U.S. CPI, BLS draft paper. http://www.bls.gov/cpi/cpicamco.htm

Shepler, Nicole, Developing a Hedonic Regression Model For Refrigerators In the U.S. CPI, BLS draft paper. http://www.bls.gov/cpi/cpirfr.htm

Soete, Luc and Bas ter Weel, Innovation, Knowledge Creation and Technology Policy: The Case of The Netherlands, De Economist, Vol. 147: 293-310, 1999.

Statistics Netherlands, R\&D en Software-onderzoek bij Bedrijven in Nederland 1999, Voorburg, 2000.

Thompson, William, Developing a Hedonic Regression Model For VCRs In the U.S. CPI”, BLS draft paper. http://www.bls.gov/cpi/cpivcrp.htm

Triplett, Jack, Price and Technological Change in a Capital Good: A Survey of Research on Computers, in: Dale Jorgenson and Ralph Landau (eds.), Technology and Capital Formation, MIT Press, 1989.

Waugh, Frederick V., Quality as a Determinant of Vegetable Prices: A Statistical Study of Quality Factors Influencing Vegetable Prices in the Boston Wholesale Market, Columbia University Press: New York, 1928 (reprinted by AMS Press: New York, 1968).

Waugh, Frederick V., Quality Factors Influencing Vegetable Prices, Journal of Farm Economics, Vol. 10: 185-196, April 1929. 